\title{
TRANSITION METAL ACTIVATION AND FUNCTIONALIZATION OF CARBON-HYDROGEN BONDS
}

\author{
PROGRESS REPORT \\ for Period December 1, 1989 - November 30, 1992
}

William D. Jones

University of Rochester

Rochester, New York 14627

June 1992

MASFFR

Prepared for

THE U. S. DEPARTMENT OF ENERGY

AGREEMENT NO. DE-FG02-86ER 13569 


\section{Table of Contents}

NOTICE

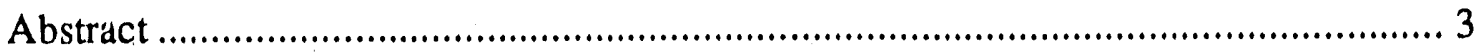

A. Previous Studies Under DOE Contract....................................................... 4

1. $\eta^{2}$-Arene Studies. .............................................................................. 4

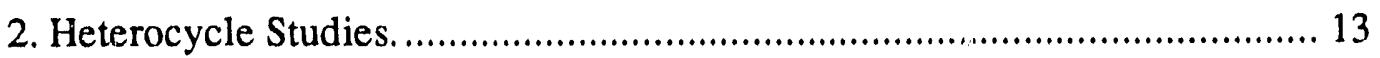

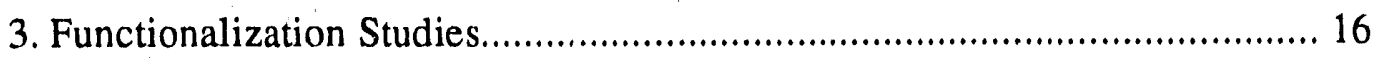

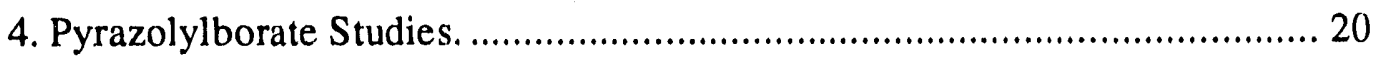

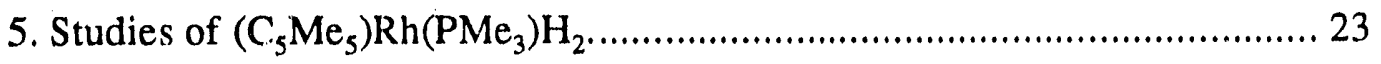

6. Effects of Phosphine on $\left(\mathrm{C}_{5} \mathrm{Me}_{5}\right) \mathrm{Rh}\left(\mathrm{PR}_{3}\right) \mathrm{PhH}$ Stability............................. 26

7. C-H Activation by Rhenium and Manganese........................................... 28

8. Rhenium Indenyl Chemistry........................................................... 28

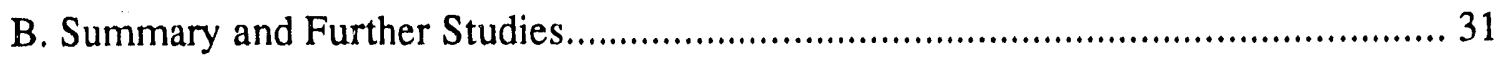

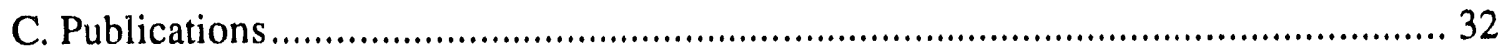

D. Papers in press or submitted .......................................................................... 36

\section{NOTICE}

This report was prepared as an account of work sponsored by the United States Government. Neither the United States nor the Department of Energy, nor any of their employees, makes any warranty, express or implied, or assumes any legal liability or responsibility for the accuracy, completeness, or usefulness of any information, apparatus, product or process disclosed or represents that its use would not infringe privatelyowned rights. 


\begin{abstract}
This project is directed towards the continued investigation of the fundamental thermodynamic and kinetic factors that influence carbon-hydrogen bond activation at homogeneous transition metal centers. The project is also directed towards the conversion of hydrocarbons into functionalized products of potential use to the chemical industry. In the past two years, advances have been made in both understanding the interactions of hydrocarbons with metals and in the functionalization of hydrocarbons. Major advances that have been made include: 1) We have found that $\mathrm{RhCl}\left(\mathrm{PR}_{3}\right)_{2}(\mathrm{CNR})$ complexes can catalyze the insertion of isonitriles into the $\mathrm{C}-\mathrm{H}$ bonds of arenes upon photolysis. The mechanism of these reactions was found to proceed by way of initial phosphine dissociation, followed by $\mathrm{C}-\mathrm{H}$ activation and isonitrile insertion. 2) We have also examined reactions of a series of arenes with $\left(\mathrm{C}_{5} \mathrm{Me}_{5}\right) \mathrm{Rh}\left(\mathrm{PMe}_{3}\right) \mathrm{PhH}$ and begun to map out the kinetic and thermodynamic preferences for arene coordination. The effects of resonance, specifically the differences in the Hückel energies of the bound vs free ligand, are now believed to fully control the $\mathrm{C}-\mathrm{H}$ activation $/ \eta^{2}$-coordination equilibria. 3) We have begun to examine the reactions of rhodium isonitrile pyrazolylborates for alkane and arene $\mathrm{C}-\mathrm{H}$ bond activation. A new, labile, carbodiimide precursor has been developed for these studies. 4) We have completed studies of the reactions of $\left(\mathrm{C}_{5} \mathrm{Me}_{5}\right) \mathrm{Rh}\left(\mathrm{PMe}_{3}\right) \mathrm{H}_{2}$ with $\mathrm{D}_{2}$ and $\mathrm{PMe}_{3}$ that indicate that both $\eta^{5} \rightarrow \eta^{3}$ ring slippage and metal to ring hydride migration occur more facilely than thermal reductive elimination of $\mathrm{H}_{2}$.5) We have examined the reactions of heterocycles with $\left(\mathrm{C}_{5} \mathrm{Me}_{5}\right) \mathrm{Rh}\left(\mathrm{PMe}_{3}\right) \mathrm{PhH}$ and found that pyrrole and furan undergo $\mathrm{C}-\mathrm{H}$ or $\mathrm{N}-\mathrm{H}$ activation. Thiophene, however, undergoes $\mathrm{C}-\mathrm{S}$ bond oxidative addition, and the mechanism of activation has been shown to proceed through sulfur coordination prior to C-S insertion.
\end{abstract}




\section{A. Previous Studies Under DOE Contract.}

\section{1. $\eta^{2}$-Arene Studies.}

The relative thermodynamic and kinetic selectivities of $\mathrm{C}-\mathrm{H}$ bond activation vs $\eta^{2}$-arene coordination have been measured for $\left[\left(\mathrm{C}_{5} \mathrm{Me}_{5}\right) \mathrm{Rh}\left(\mathrm{PMe}_{3}\right)\right]$ by thermolysis of $\left(\mathrm{C}_{5} \mathrm{Me}_{5}\right) \mathrm{Rh}\left(\mathrm{PMe}_{3}\right)(\mathrm{Ph}) \mathrm{H}$ in hexane solution in the presence of an arene. With naphthalene, a 2:1 equilibrium is set up between $\left(\mathrm{C}_{5} \mathrm{Me}_{5}\right) \mathrm{Rh}\left(\mathrm{PMe}_{3}\right)\left(\eta^{2}\right.$-naphthalene $)$ and $\left(\mathrm{C}_{5} \mathrm{Me}_{5}\right) \mathrm{Rh}\left(\mathrm{PMe}_{3}\right)(2$-naphthyl)H, both of which are preferred over $\left(\mathrm{C}_{5} \mathrm{Me}_{5}\right) \mathrm{Rh}\left(\mathrm{PMe}_{3}\right)(\mathrm{Ph}) \mathrm{H}$. Furthermore, the rate of loss of naphthalene from $\left(\mathrm{C}_{5} \mathrm{Me}_{5}\right) \mathrm{Rh}\left(\mathrm{PMe}_{3}\right)\left(\eta^{2}\right.$-naphthalene) was measured by monitoring the kinctics of the conversion back to $\left(\mathrm{C}_{5} \mathrm{Me}_{5}\right) \mathrm{Rh}\left(\mathrm{PMe}_{3}\right)(\mathrm{Ph}) \mathrm{H}$ in neat benzene, giving the overall barrier for naphthalene loss. Combining these kinetic and thermodynamic data with those previously established for benzene gives the free energy diagram shown in Scheme I. ${ }^{1}$

The barrier for interconversion of the naphthyl hydride complex and the $\eta^{2}$ naphthalene complex was determined by ${ }^{31} \mathrm{P}$ spin saturation transfer (SST) experiments. For the rate of loss of the naphthyl hydride complex, the activation parameters were determined $\left(\Delta H^{\ddagger}=16.9(7) \mathrm{Kcal} /\right.$ mole, $\Delta S^{\ddagger}=-8.1(2)$ e.u. $),{ }^{2}$ which compare favorably with the previously determined values for the formation of $\left(\mathrm{C}_{5} \mathrm{Me}_{5}\right) \mathrm{Rh}\left(\mathrm{PMe}_{3}\right)\left(\eta^{2}-\mathrm{p}-\right.$ xylene) from $\left(\mathrm{C}_{5} \mathrm{Me}_{5}\right) \mathrm{Rh}\left(\mathrm{PMe}_{3}\right)(\mathrm{p}$-xylyl $) \mathrm{H}\left(\Delta \mathrm{H}^{\ddagger}=16.3(2) \mathrm{Kcal} / \mathrm{mole}, \Delta \mathrm{S}^{\ddagger}=-6.3(8)\right.$ e.u.), ${ }^{3}$ indicating that dropping the energy of the $\eta^{2}$-naphthalene complex has little effect upon the transition state for aryl-hydride to $\eta^{2}$-arene interconversion. The depth of the well for $\left(\mathrm{C}_{5} \mathrm{Me}_{5}\right) \mathrm{Rh}\left(\mathrm{PMe}_{3}\right)\left(\eta^{2}\right.$-benzene $)$ has been independently determined in flash photolysis experiments done in collaboration with Dr, Robin Perutz of the University of York, where the P.I. spent a sabbatical leave. These studies showed that the intermediate

(1) Jones, W. D.; Dong, 1... J. Am. Chem. Soc. 1989, 111, 8722-8723.

(2) Belt, S. T.; Dong, L.; Duckett, S. B.; D. Jones, W. D.; Partridge, M. G.; and Perutz, R. N. J. Chem. Soc., Chem. Commun. 1991, 266-269.

(3) Jones, W. D.; Feher, F. J. J. Amer. Chem. Sec., 1984, 106, 1650-1663. 
$\left[\left(\mathrm{C}_{5} \mathrm{Me}_{5}\right) \mathrm{Rh}\left(\mathrm{PMe}_{3}\right)\right]$ reacts rapidly (<200 ns) to give the $\eta^{2}-\mathrm{C}_{6} \mathrm{H}_{6}$ complex, which then goes on more slowly ( $\tau \cong 150 \mu \mathrm{s})$ to insert into the $\mathrm{C}$-H bond. The activation parameters for this step of the reaction were also determined, giving $\Delta H^{\ddagger}=11.15(0.31) \mathrm{Kcal} / \mathrm{mole}$ and $\Delta S^{\ddagger}=-4.9(1.1)$ e.u.

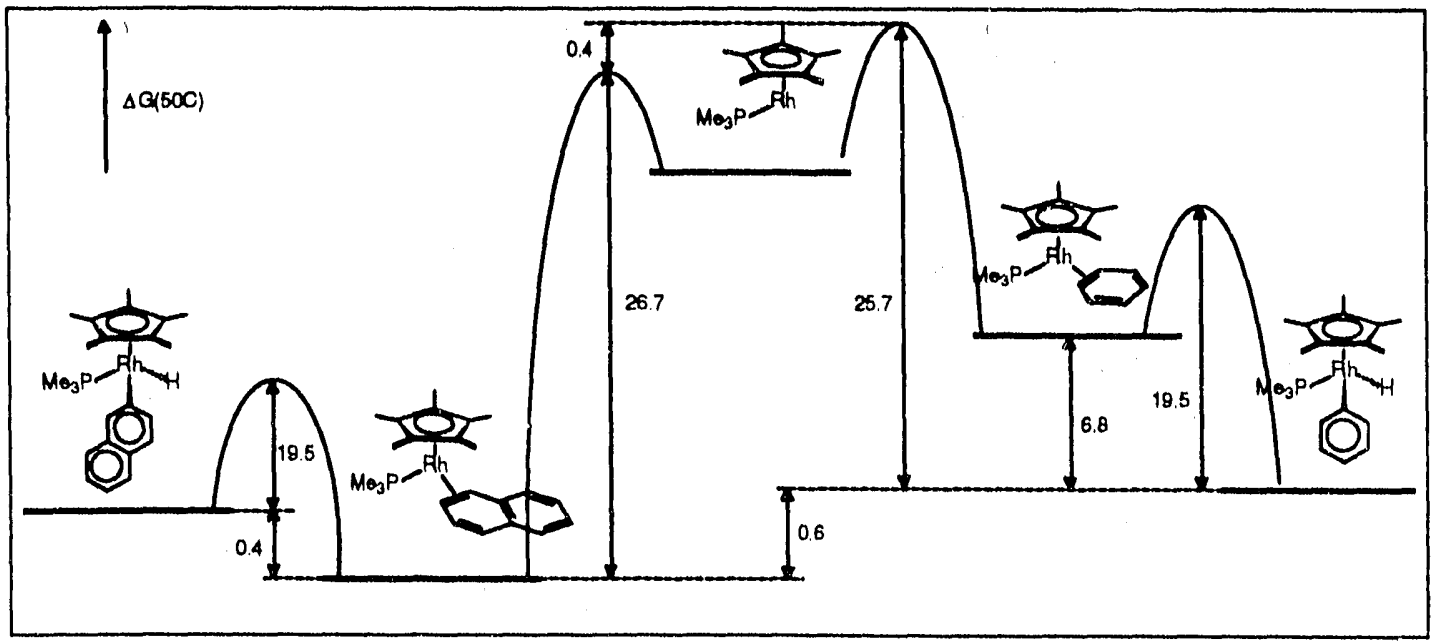

Scheme I. Free Energy diagram for benzene and naphthalene complexes.

As can be seen, the unique feature about the polycyclic aromatic lies in the stability of the $\eta^{2}$ complex relative to the naphthyl hydride complex. That is, for benzene, the $\eta^{2}$-complex is destabilized relative to the $\eta^{2}$-naphthalene complex, whereas the $\mathrm{C}-\mathrm{H}$ activation complexes are of comparable energy. It is becoming clear that it is the energy of the $\eta^{2}$ complex that determines whether or not $C$-H oxidative addition will occur, and that the bond strengths should not be the only factor considered. The origin of this destabilization can be directly attributed to the interruption of the resonance of the aromatic ring, which is minimized in the naphthalcze complex. Table I summarizes calculations of the energies of the free and bound arene in terms of the p-orbital interaction integral $\beta$. The balance point for $\mathrm{C}-\mathrm{H}$ activation vs $\eta^{2}$ coordination occurs at $\Delta \mathrm{E}_{\mathrm{r}} \cong 1.25 \beta$. Values larger than this give $\mathrm{C}-\mathrm{H}$ activation only, and smaller values result in only $\eta^{2}$-arene complexation (vide infra). Other examples support this hypothesis, as outlined in Scheme II and summarized below. 
Table I. Resonance Energies for $\eta^{2}$-Arene Complexes (in units of $\beta$ ).

\begin{tabular}{|c|c|c|c|}
\hline \multirow[t]{2}{*}{ Complex } & \multicolumn{2}{|c|}{ Resonance Energy of } & $\Delta \mathrm{E}_{\mathrm{r}}$ \\
\hline & Free Arene & $\eta^{2}$-Arene & $\beta(\mathrm{Kcal} / \mathrm{mol})$ \\
\hline & 2 & 0.47 & $1.53(30.6)$ \\
\hline & 3.68 & 2.42 & $1.26(25.2)$ \\
\hline & 3.68 & 1.95 & $1.73(34.6)$ \\
\hline & 3.68 & 2.00 & $1.68(33.6)$ \\
\hline & 3.68 & 0.99 & $2.69(53.8)$ \\
\hline & 4.43 & 3.39 & $1.04(20.8)$ \\
\hline & 4.43 & 3.19 & $1.24(24.8)$ \\
\hline & 4.43 & 3.14 & $1.29(25.8)$ \\
\hline & 5.31 & 4.11 & $1.20(24.0)$ \\
\hline & 5.31 & 3.53 & $1.82(36.4)$ \\
\hline va & 5.45 & 4.38 & $1.07(21.4)$ \\
\hline & 5.45 & 4.13 & $1.32(26.4)$ \\
\hline & 5.45 & 4.11 & $1.34(26.8)$ \\
\hline
\end{tabular}




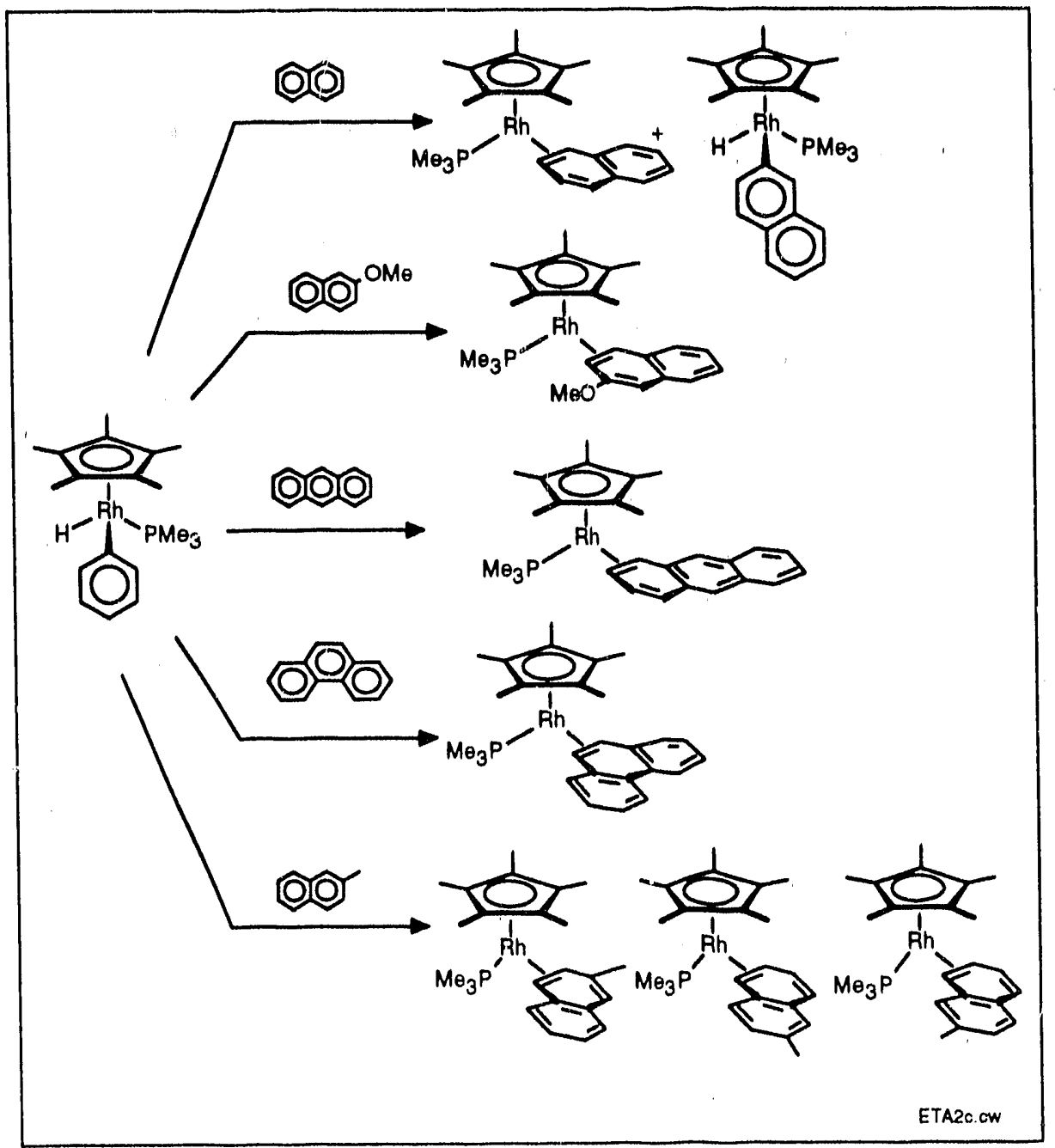

Scheme II. Reactions of polycyclic aromatics with $\left(\mathrm{C}_{5} \mathrm{Me}_{5}\right) \mathrm{Rh}\left(\mathrm{PMe}_{3}\right) \mathrm{PhH}$.

With 2-methoxynaphthalene, only the $\eta^{2}$-complex is observed in the 3,4 position of the ring. No C-H activation is seen. In this example, the loss of resonance energy is minimal $\left(\Delta \mathrm{E}_{\mathrm{r}}=1.04 \beta\right.$, Table $\left.\mathrm{I}\right)$, so that the aromatic behaves as an olefin! The reactivity is similar to that of styrene, which also forms only an $\eta^{2}$ complex with the vinylic portion of the molecule. Other simple arene selectivities (thermodynamic, since the arenes exchange under the reaction conditions) are indicated in Scheme II. With phenanthrene and anthracene, only a single $\eta^{2}$ complex is seen, again in accord with the $\Delta E_{r}$ calculations in Table I. With 2-rnethylnaphthalene, however, three different $\eta 2$ complexes are observed since they all have comparable $\Delta \mathrm{E}_{\mathrm{r}}$ energies. 
In the case of phenanthrene, the $\eta^{2}$ complex was crystallized and structurally characterized (Figure 1). Two structural features are to be noted: 1) only 2 carbons interact symmetrically with the metal and 2) the arene ring is oriented away from the phosphine and towards the $\mathrm{C}_{5} \mathrm{Me}_{5}$ ring. The UV-visible spectrum (Figure 2) of the red complex is interpreted in terms of metal to ligand $\pi^{*}$ charge transfer bands that are shifted to lower energy than the $\pi \longrightarrow \pi^{*}$ bands in free phenanthrene.

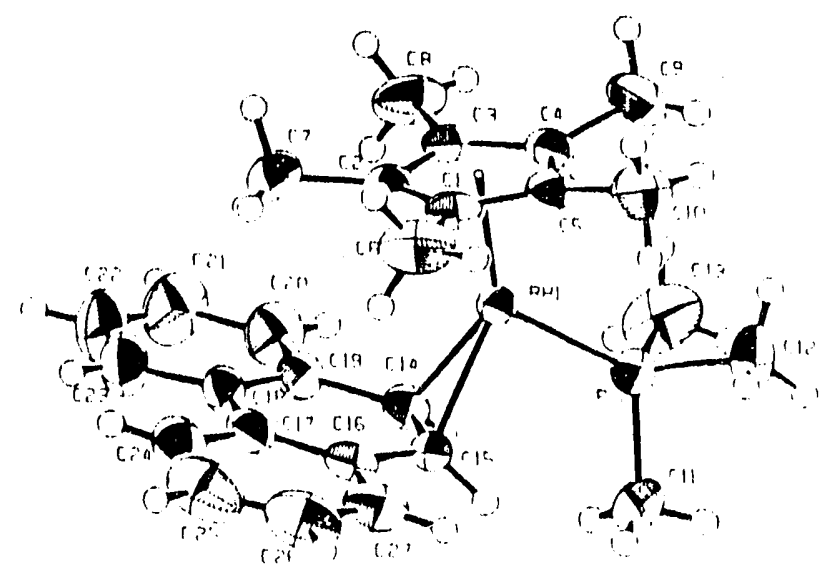

Figure 1. $\mathrm{X}$-ray of $\left(\mathrm{C}_{5} \mathrm{Me}_{5}\right) \mathrm{Rh}\left(\mathrm{PMe}_{3}\right)\left(\eta^{2}\right.$-phenanthrene $)$.

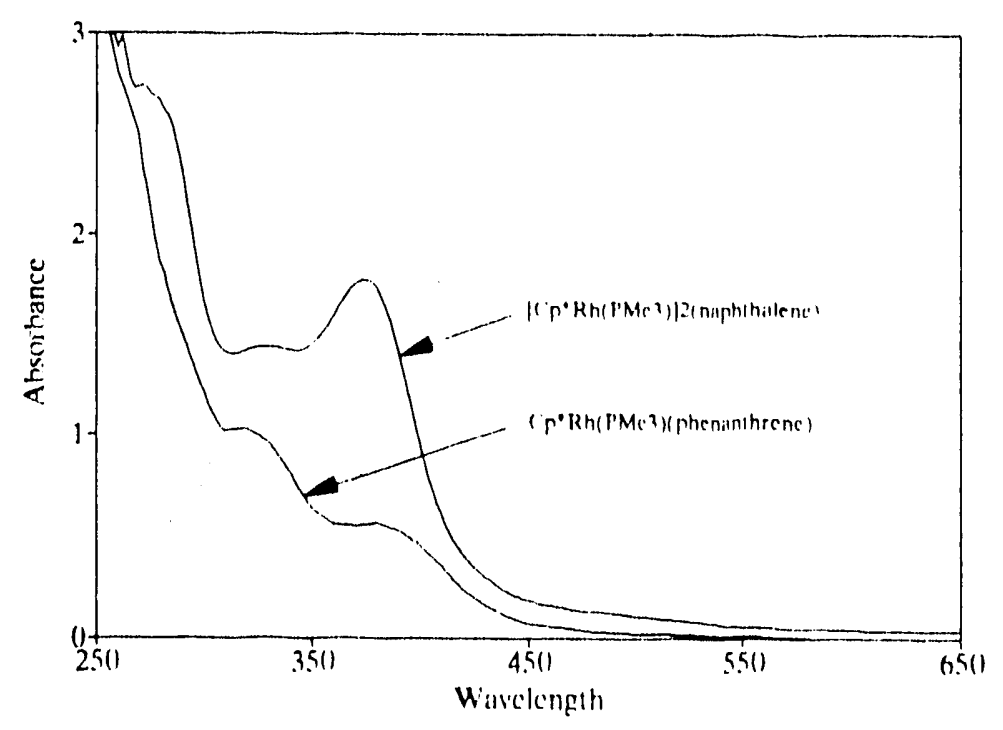

Figure 2. UV of $\left(\mathrm{C}_{5} \mathrm{Me}_{5}\right) \mathrm{Rh}\left(\mathrm{PMe}_{3}\right)\left(\eta^{2}\right.$-phenanthrene). 
The 2-methoxynaphthalene derivative also offered the opportunity to study the kinetic isomers of the reaction. Preparation of $\left(\mathrm{C}_{5} \mathrm{Me}_{5}\right) \mathrm{Rh}\left(\mathrm{PMe}_{3}\right)$ [6-(2methoxynaphthalene)]H was performed by way of hydridic reduction of the corresponding bromide complex. The initially formed aryl hydride complex rapidly isomerized between four species by way of rhodium-hydride $\longrightarrow \eta^{2}$-arene equilibria, assigned as shown in Scheme III. This result is to be expected, as the $\Delta \mathrm{E}_{\mathrm{r}}$ values from Table I are 1.24 and 1.29. Over several days time at room temperature, the four isomers were converted into the single more stable thermodynamically preferred isomer. This isomerization required migration past the carbon at the ring juncture, and consequently occurred more slowly.

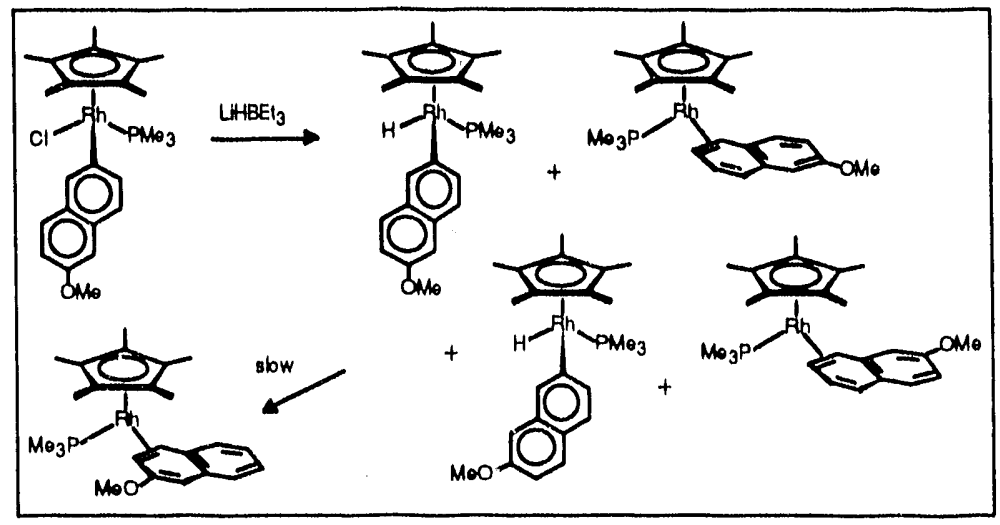

Scheme III. 2-methoxynaphthalene interconversions.

Similar rearrangements have been probed in the parent naphthalene system.

Reaction of the complex $\left(\mathrm{C}_{5} \mathrm{Me}_{5}\right) \mathrm{Rh}\left(\mathrm{PMe}_{3}\right)\left(2\right.$-naphthyl) $\mathrm{Br}$ with LiDBEt $t_{3}$ gives a mixture of 4 isomers in which the deuterium has scrambled over the two possible 2-naphthyl derivatives and two possible $\eta^{2}$ isomers (Scheme IV). Slowly, the initial isomers equilibrate with the four isomers in which the rhodium has migrated across to the unsubstituted ring. Since this rearrangement occurs more rapidly than the rate at which naphthalene dissociates from $\left(\mathrm{C}_{5} \mathrm{Me}_{5}\right) \mathrm{Rh}\left(\mathrm{PMe}_{3}\right)\left(\eta^{2}\right.$-naphthalene), the reaction must be intramolecular. 


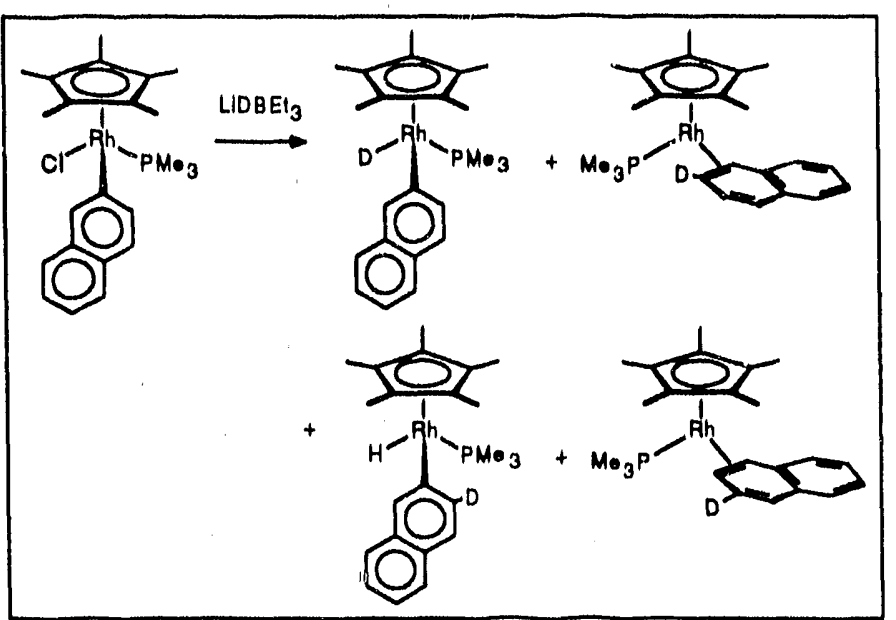

Scheme IV. Naphthalene- $\mathrm{d}_{1}$ interconversions.

Further heating of the reaction of $\left(\mathrm{C}_{5} \mathrm{Me}_{5}\right) \mathrm{Rh}\left(\mathrm{PMe}_{3}\right) \mathrm{PhH}$ with naphthalene ultimately leads to a new thermodynamically preferred product in which two rhodiums are attached to the aromatic ligand. Periodic removal of naphthalene helps to shift this equilibrium towards the binuclear adduct, allowing its isolation and characterization in pure form. COSY NMR studies indicate that both metals are on one aromatic ring. The $\mathrm{X}$-ray structure, shown in Figure 3, confirms that both metals are on the same aromatic ring but on opposite faces. The preference for keeping the aromatic ring pointing up towards the $\mathrm{Cp}^{*}$ ring can also be seen here, as in the phenanthrene complex.

The $\Delta \mathrm{E}_{\mathrm{r}}$ calculation for the possible binuclear adducts given in Ta Jle $\mathrm{I}$ are in agreement with the observed isomer. While the large value of $\Delta \mathrm{E}_{\mathrm{r}}(1.68)$ would suggest that only $\mathrm{C}-\mathrm{H}$ activation should be observed, this energy cost should be divided over two metal-arene interactions, giving a $\Delta \mathrm{E}_{\mathrm{r}}$ of 0.84 per metal, which is well within the $\eta^{2}$ regime.

A variety of other larger fused polycyclic aromatics have also been examined. These include pyrene, perylene, fluoranthene, and triphenylene. Preliminary studies indicate that in most cases $\eta^{2}$ arene complexation is strongly preferred, but that in others $\mathrm{C}-\mathrm{H}$ activation is preferred (Scheme V). As in the earlier cases, examination of the 
resonance energy costs based on simple Hückel energies allows one to account for the observations. The results of these calculations are summarized in Table II.

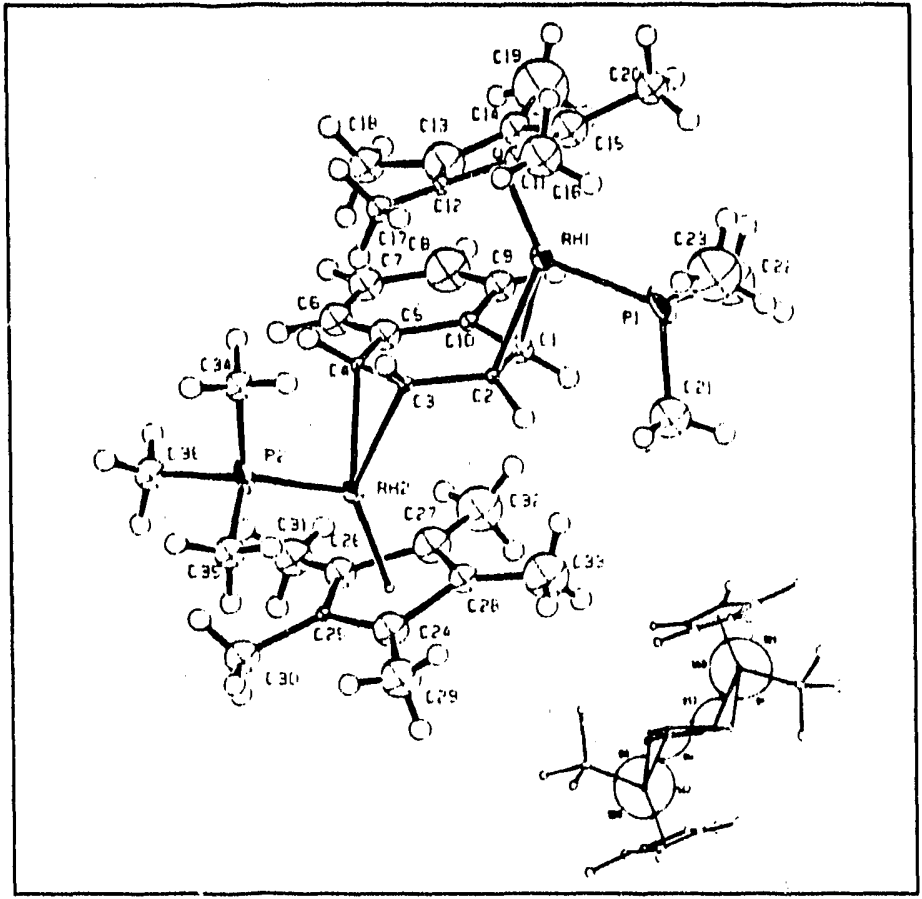

Figure 3. ORTEP drawing of $\left[\left(\mathrm{C}_{5} \mathrm{Me}_{5}\right) \mathrm{Rh}\left(\mathrm{PMe}_{3}\right)\right]_{2}$ (naphthalene).

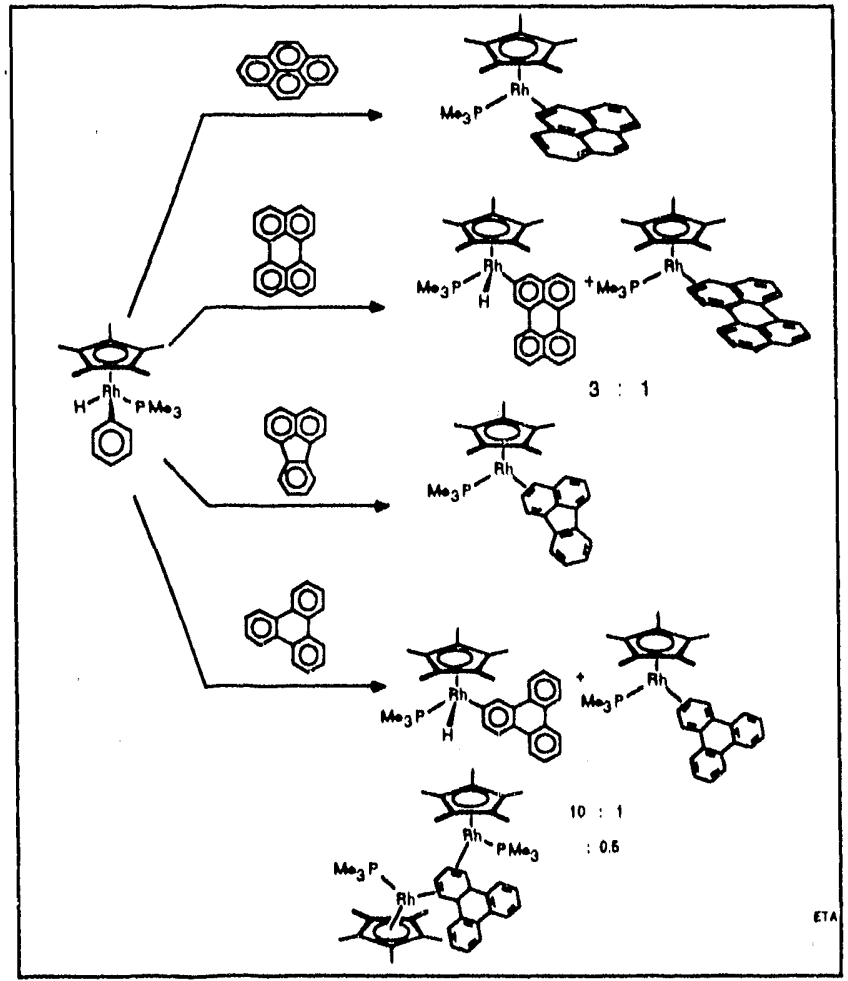

Scheme V. Reactions with larger fused polycyclic aromatics. 
Table II. Resonance Energies for $\eta^{2}$-Arene Complexes (in units of $\beta$ ).

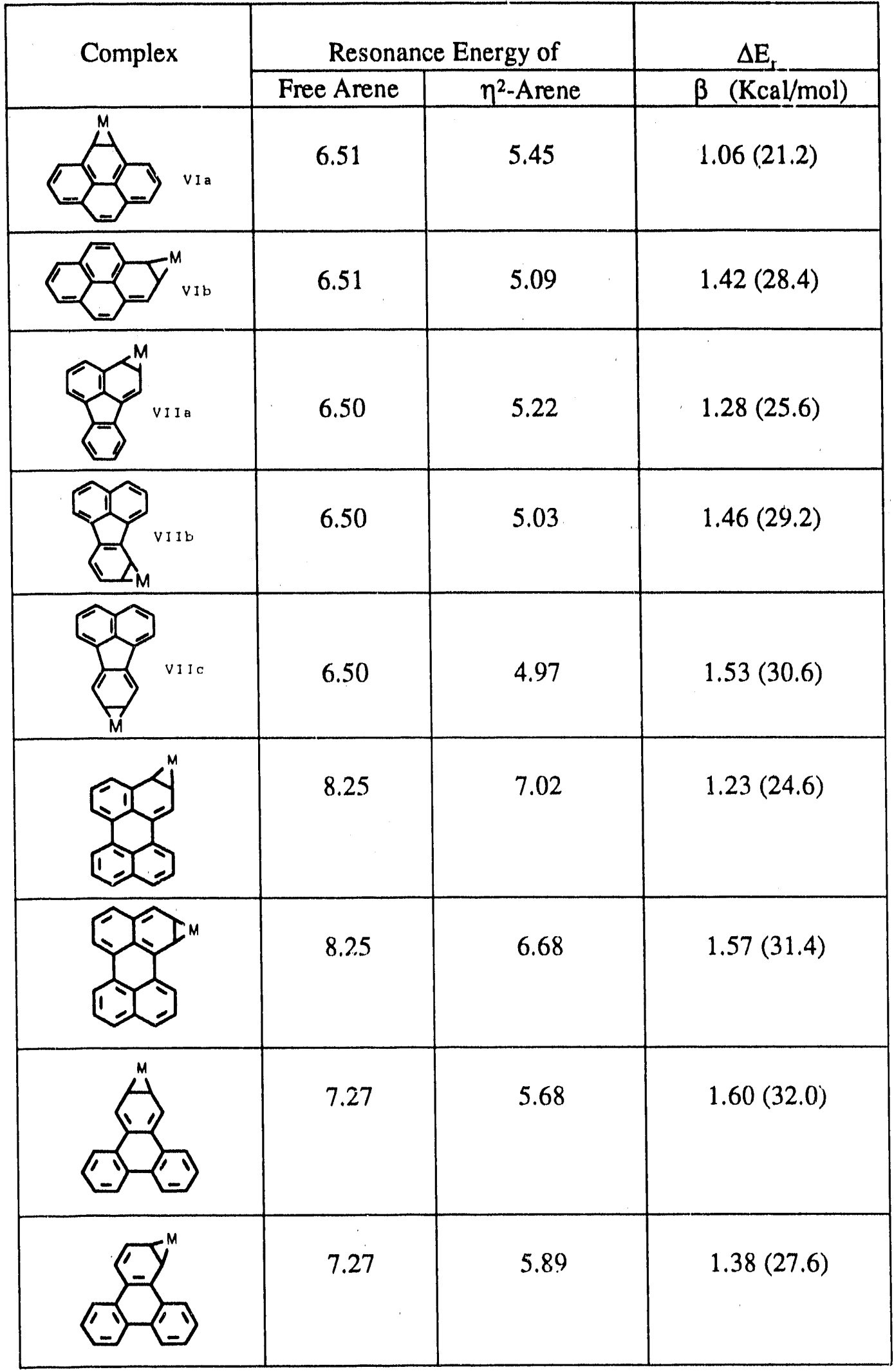




\section{Heterocycle Studies.}

We have also examined the reactions of $\left(\mathrm{C}_{5} \mathrm{Me}_{5}\right) \mathrm{Rh}\left(\mathrm{PMe}_{3}\right) \mathrm{PhH}$ with several heterocyclic aromatics. Reaction with furan gives only the $\mathrm{C}-\mathrm{H}$ activation product in which the $\alpha \mathrm{C}-\mathrm{H}$ bond has been cleaved (Scheme VI). A similar reaction with 2,3dihydrofuran, which contains a vinylic $\mathrm{C}-\mathrm{H}$ bond of the same strength, gives only the $\eta^{2}$ complex. Again, the $\mathrm{C}-\mathrm{H}$ bond activation of furan is interpreted in terms of the cost in energy (due $\mathrm{t}$ disruption of aromaticity) for $\eta^{2}$-coordination to the furan ring. The $\mathrm{C}-\mathrm{H}$ bond activation can be driven to the $\beta$ position if the $\alpha$-positions are blocked with methyl groups.

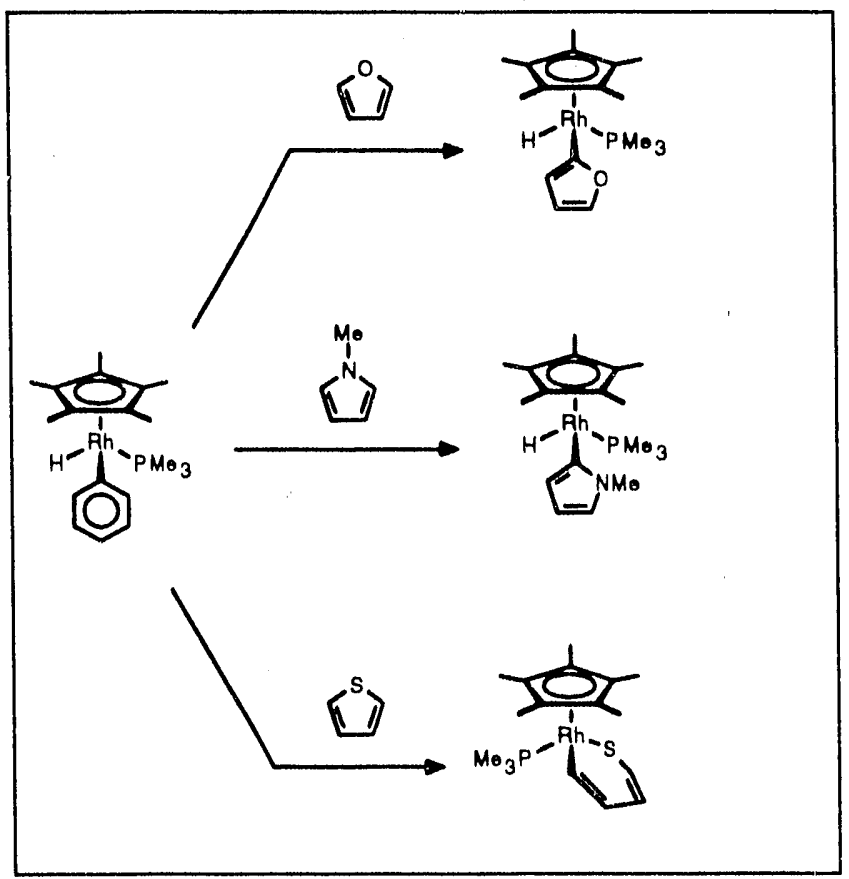

Scheme VI. Heterocycle reactions.

Reaction of $\left(\mathrm{C}_{5} \mathrm{Me}_{5}\right) \mathrm{Rh}\left(\mathrm{PMe}_{3}\right) \mathrm{PhH}$ with pyrrole was also examined. In this case, only N-H activation was observed. Replacement of the amino hydrogen with a methyl group led to activation of the $\alpha-\mathrm{C}-\mathrm{H}$ bond. Reaction with pyrazole led to a mixture of products, with both $\mathrm{N}-\mathrm{H}$ and $\mathrm{C}-\mathrm{H}$ activation observed. 
Reaction of $\left(\mathrm{C}_{5} \mathrm{Me}_{5}\right) \mathrm{Rh}\left(\mathrm{PMe}_{3}\right) \mathrm{PhH}$ with thiophene was also examined for comparison with the other heterocycles. ${ }^{4}$ It was anticipated that the $\eta^{2}$-complex might now be seen in equilibrium with the $\mathrm{C}$-H activation product, since thiophene has a lower resonance energy than either furan or pyrrole. Much to our surprise, however, a single new product was formed in high yield in which the rhodium had inserted into the C-S bond of the thiophene! An X-ray crystal structure of the material formed with 2,5dimethylthiophene (Figure 4) showed a localized diene structure with a normal rhodium to $\mathrm{sp}^{2}$-carbon bond. Other thiophenes such as benzothiophene and dibenzothiophene also react similarly. 2-methylthiophene gives only a single product ir: which only the unsubstituted C-S bond undergoes addition.

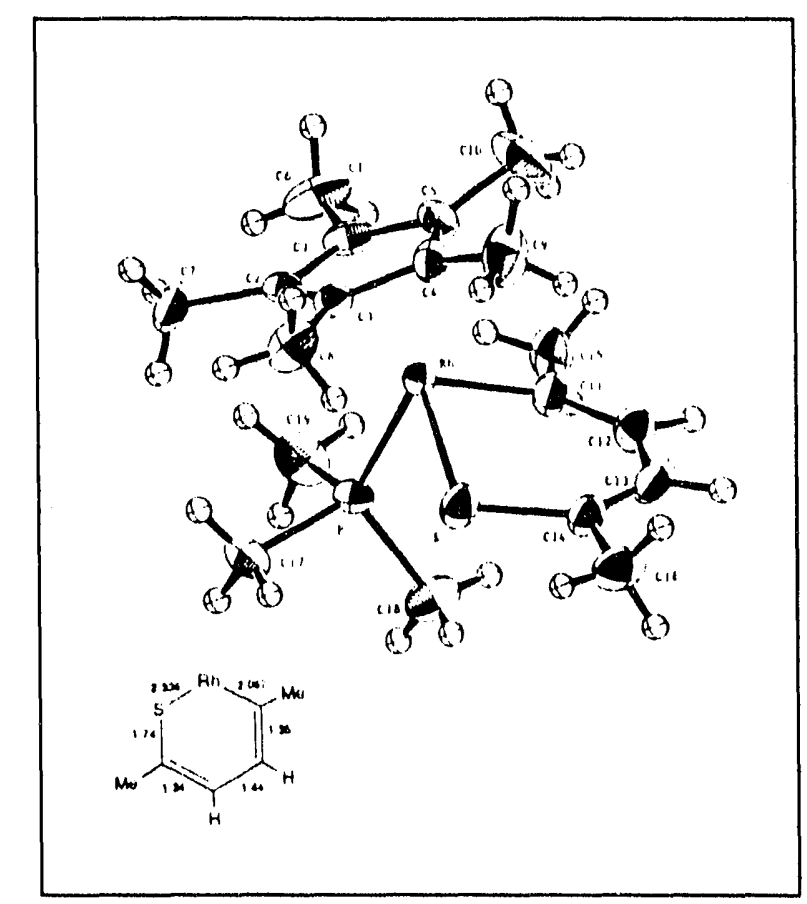

Figure 4. $\mathrm{X}$-ray of $\left(\mathrm{C}_{5} \mathrm{Me}_{5}\right) \mathrm{Rh}\left(\mathrm{PMe}_{3}\right)$ (thiophene).

Some information was also obtained about the mechanism of the thiophene activation. A competition experiment was performed by heating $\left(\mathrm{C}_{5} \mathrm{Me}_{5}\right) \mathrm{Rh}\left(\mathrm{PMe}_{3}\right) \mathrm{PhH}$ in a 1:1 mixture of thiophene and 2,5-dimethylthiophene. A 2:1 ratio of the two insertion

(4) Jont's, W. D.; Dong, L. J. Am. Chem. Soc. 1991, 113, 559-564. 
products was formed. Three mechanisms were postulated for the insertion reaction, as indicated in Scheme IV.

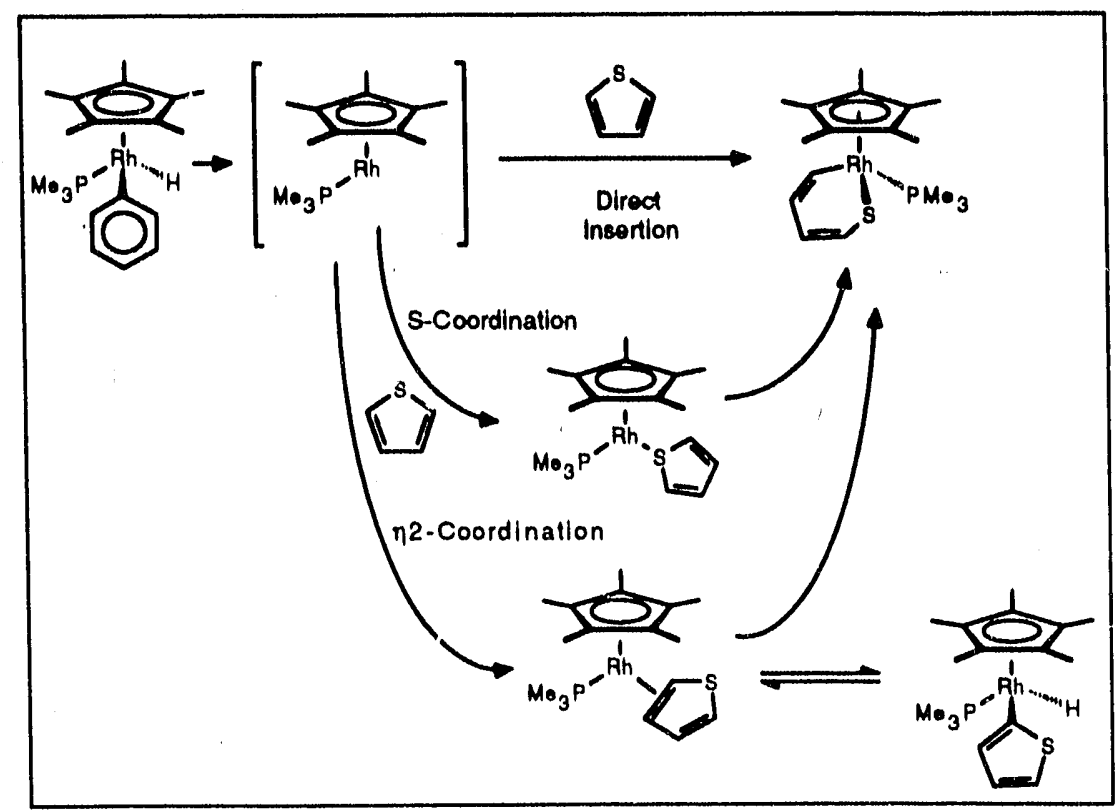

Scheme IV. C-S insertion mechanisms.

Since the selestivity in this experiment was differeit $\quad$ an that observed with 2 methylthiophene, the direct insertion of rhodium into the C-S bond can be ruled out. Another possible mechanism would involve initial $\pi$-bonding of the thiophene in an $\eta^{2}$ fashion prior to C-S insertion. However, the otservation that 2-methylthiophene gives only a single insertion product would dictate that the unsubstituted double bond preferentially coordinates to the metal center. This in turn would require that only thiophene be activated in the competition experiment. Since both thiophene and 2,5dimethylthiophene were in fact activated, the $\eta^{2}$-thiophene complex can be discounted as the precursor for $\mathrm{C}-\mathrm{S}$ bond cleavage. A third possibility is that the thiophene coordinates through the sulfur prior to activation. If this coordination is irreversible, then either thiophene or dimethylthiophene can S-coordinate to the metal, and both insertion products would be formed. With 2-methylthiophene, S-coordination would be followed by migration of only the unsubstituled carbon to the metal, giving rise to only a single 
insertion isomer as shown in Scheme V. As this investigation will require substantial effort to follow up on, independent funding for sulfur chemistry has been obtained from the NSF.

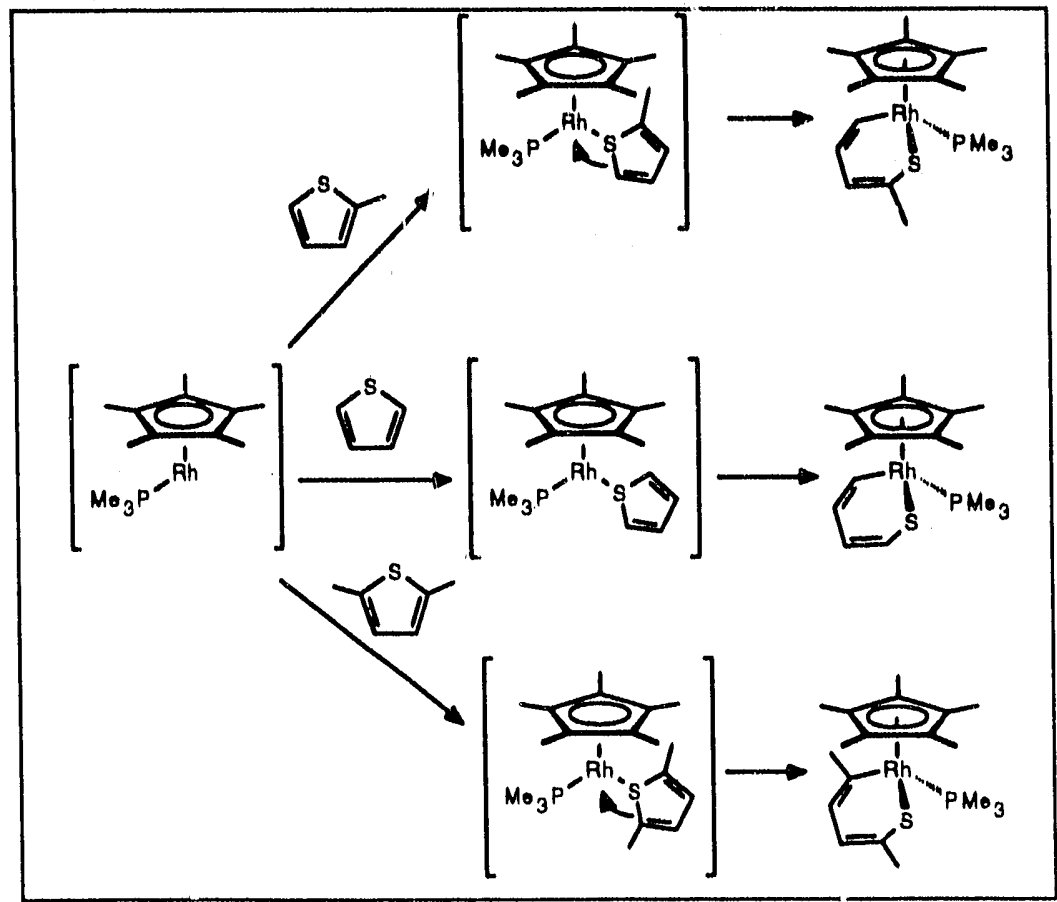

Scheme V. Thiophene activation via S-coordination.

\section{Functionalization Studies.}

We have synthesized a series of square planar $\mathrm{Rh}(\mathrm{I})$ complexes that are active in the catalytic functionalization of hydrocarbons. So far, isonitriles can be inseried into aromatic $\mathrm{C}-\mathrm{H}$ bonds under photochemical conditions. ${ }^{5}$ The catalysts employed are of the variety $\mathrm{RhCl}\left(\mathrm{PR}_{3}\right)_{2}\left(\mathrm{CNR}^{\prime}\right)$ where $\mathrm{R}=\mathrm{Me}, \mathrm{Et}, \mathrm{i}-\mathrm{Pr}$ and $\mathrm{R}^{\prime}=$ neopentyl or 2,6-xylyl. The complexes are prepared by the route shown in Eq 1. Several of the complexes have been structurally characterized as indicated in Figure 4. Irradiation of benzene solutions of these complexes in the presence of added isonitrile in millimolar concentrations results in the catalytic formation of aldimines (Eq 2). Table III gives typical conversions.

(5) Jones, W. D.; Hessell, E. T. Organometallics 1990, 9, 718-72.7. 

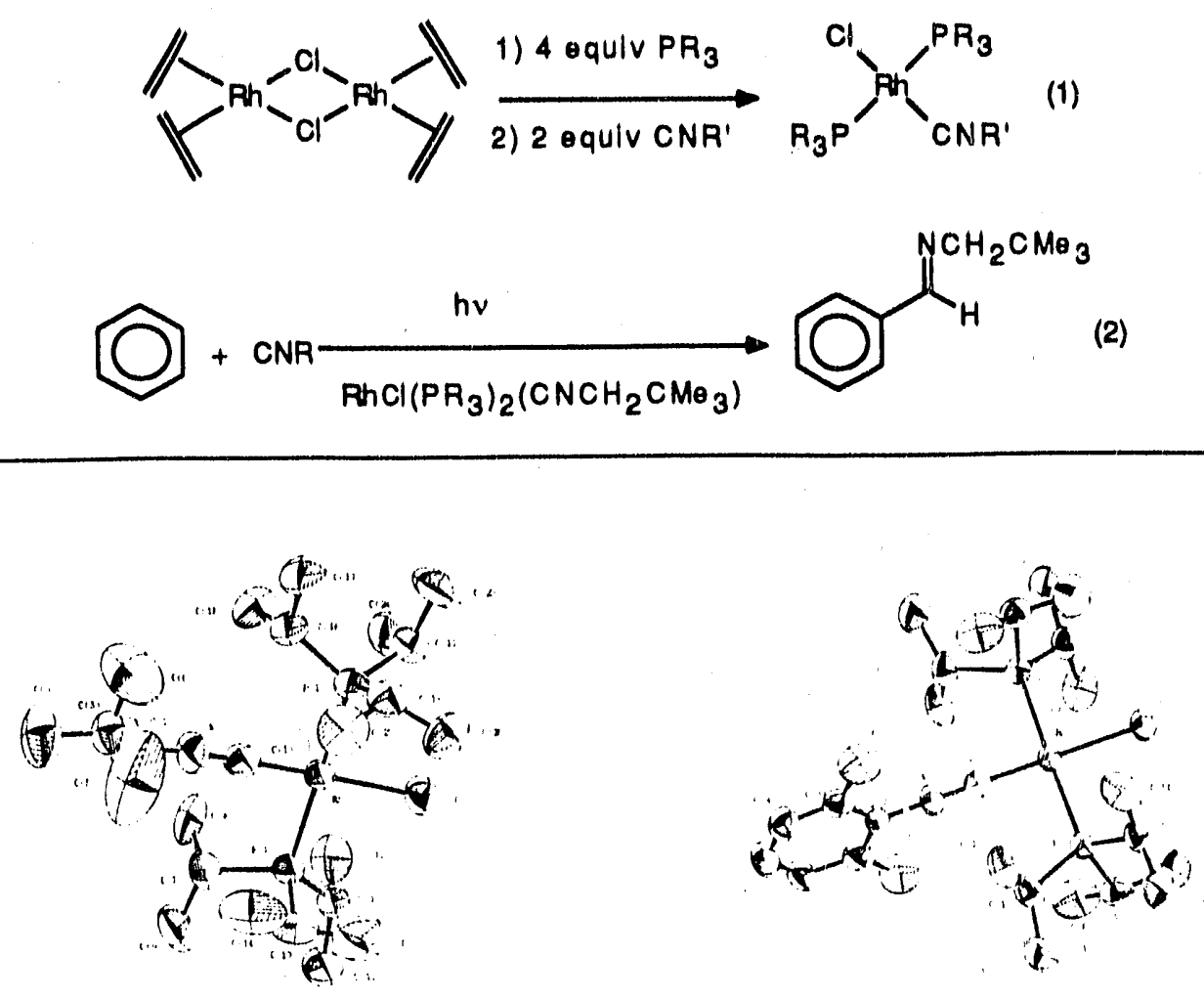

Figure 4. $\mathrm{X}^{\prime}$-ray of $\mathrm{RhCl}\left(\mathrm{P}-i \mathrm{Pr}_{3}\right)_{2}(\mathrm{CNneopentyl})$ and $\mathrm{RhCl}\left(\mathrm{P}-i \mathrm{Pr}_{3}\right)_{2}(\mathrm{CNxylyl})$.

The experiments indicate that phosphine is an efficient poison for the catalysis, but that isonitrile is not. This observation is interpreted as providing evidence for the photochemical dissociation of phosphine followed by the oxidative addition of benzene, the insertion of isonitrile and coordination of phosphine, and the reductive elimination of aldimine as shown in Scheme VI.

Further support for the role of phosphine dissociation comes from the observation that the chelated complex $\mathrm{RhCl}(\mathrm{CNneopentyl})\left[(i \text { - } \mathrm{Pr})_{2} \mathrm{PCH}_{2} \mathrm{CH}_{2} \mathrm{P}(i \text { - } \mathrm{Pr})_{2}\right]$ does not catalyze the functionalization of arenes. We have also varied the length of the chelate in an effort to tune the re-association of phosphine. However, no catalytic activity was seen with the diisopropylphosphino propylene or butylene derivatives. The iodide complex was also examined, and found to be a less efficient catalyst than the chloride. ${ }^{6}$

(6) Jones, W. D.; Hessell, E. T. Nouv. J. Chem. 1990, 14, $481-485$. 
Table IIY. Yields for Catalytic Reactions of $\mathrm{RhCl}\left(\mathrm{PR}_{3}\right)_{2}(\mathrm{CNneopentyl).}$

\begin{tabular}{|c|c|c|c|c|c|c|}
\hline Entry & $\mathbf{R}$ & {$[\mathrm{Rh}], \mathrm{mM}$} & {$[\mathrm{CNR}]^{\mathrm{a}}, \mathrm{mM}$} & Hrs irrad & \%conversion ${ }^{\mathrm{b}}$ & turnovers \\
\hline 1 & $\mathrm{Me}$ & 0.2 & 1.0 & 16 & 62 & 3.7 \\
\hline 2 & $\mathrm{Et}$ & 0.2 & 1.0 & 16 & 33 & 2.0 \\
\hline 3 & $\mathrm{i}-\mathrm{Pr}$ & 0.2 & 1.0 & 16 & 76 & 4.5 \\
\hline 4 & $\mathrm{i}-\operatorname{Pr}$ & 0.05 & 1.0 & 16 & 27 & 5.9 \\
\hline 5 & $\mathrm{i}-\operatorname{Pr}$ & 0.05 & 0.5 & 16 & 68 & 7.7 \\
\hline 6 & i-Pr & 0.2 & 1.0 & 2 & 20 & 1.2 \\
\hline 7 & $\mathrm{i}-\operatorname{Pr}$ & 0.2 & 1.0 & 4 & 35 & 2.1 \\
\hline 8 & $\mathrm{i}-\operatorname{Pr}$ & 0.2 & 1.0 & 8 & 53 & 3.2 \\
\hline 9 & i-Pr & 0.2 & 1.0 & 12 & 60 & 3.6 \\
\hline 10 & $\mathrm{i}-\mathrm{Pr}$ & 0.2 & 1.0 & 16 & 59 & 3.6 \\
\hline 11 & $\mathrm{i}-\operatorname{Pr}$ & 0.2 & 1.0 & 20 & 64 & 3.8 \\
\hline 12 & $\mathrm{i}-\mathrm{Pr}$ & 0.2 & c & 16 & 97 & - \\
\hline 13 & - & - & c & 16 & 94 & - \\
\hline 14 & i-Pr & 0.2 & 1.0 & 16 & 58 & 3.5 \\
\hline 15 & $\mathrm{i}-\mathrm{Pr}$ & 0.2 & 1.0 & 9 & 45 & 2.2 \\
\hline 16 & $\mathrm{i}-\operatorname{Pr}$ & 0.2 & $1.0^{\mathrm{d}}$ & 9 & 47 & 2.8 \\
\hline 17 & i-Pr & 0.2 & 2.0 & 4 & 25 & 1.3 \\
\hline 18 & i- $\operatorname{Pr}$ & 0.2 & 3.0 & 4 & 8 & 0.5 \\
\hline 19 & $\mathrm{i}-\mathrm{Pr}$ & 0.2 & $1.0^{\mathrm{e}}$ & 4 & 3.4 & 0.2 \\
\hline 20 & $\mathrm{i}-\mathrm{Pr}$ & 0.2 & $1.0^{\mathrm{f}}$ & 4 & 2.8 & 0.2 \\
\hline
\end{tabular}

(a) Neopentylisonitrile unless otherwise indicated.

(b) Based on total isonitrile present (metal bound and free) going to form aldimine.

(c) $\left.1 \mathrm{mM}\left[\mathrm{Rh}\left(\mathrm{P}-\mathrm{PPr}_{3}\right)_{2} \text { (CNneopentyl }\right)_{2}\right]^{+}$used instead of CNR.

(d) Performed under $1 \mathrm{~atm}$ CO.

(e) $1 \mathrm{mM}$ triisopropylphosphine added.

(f) $2 \mathrm{mM}$ triisopropylphosphine added.

The mode of deactivation of the catalyst is not known. It was established that reaction of higher concentrations of isonitrile with $\mathrm{RhCl}(\mathrm{CNR})\left(\mathrm{PR}_{3}\right)_{2}$ leads to the formation of the insoluble cations $\left[\mathrm{Rh}\left(\mathrm{PR}_{3}\right)_{2}\left(\mathrm{CNR}^{\prime}\right)_{2}\right]^{+} \mathrm{Cl}$, characterized by $\mathrm{X}$-ray diffraction (Figure 6). However, a slurry of this material in benzene still constitutes an active catalyst solution. Exchange of the chloride counterion for $\mathrm{BF}_{4}$, however, gives a salt that is inactive under identical conditions, suggesting that coordination of chloride ion is required to form the active catalyst. None of these catalysts (neutral or salt) has been found to be active for alkane functionalization, although lack of solubility may be the primary problem. 


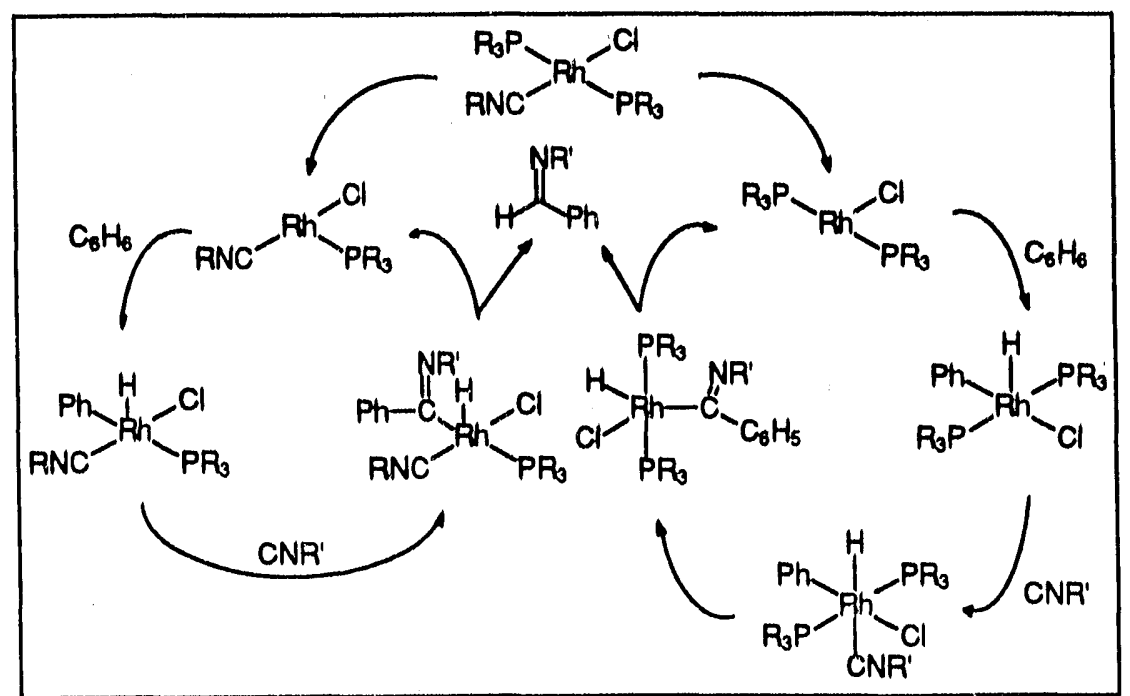

Scheme VI. Mechanism of aldimine formation with $\mathrm{RhCl}\left(\mathrm{PR}_{3}\right)_{2}(\mathrm{CNR})$.

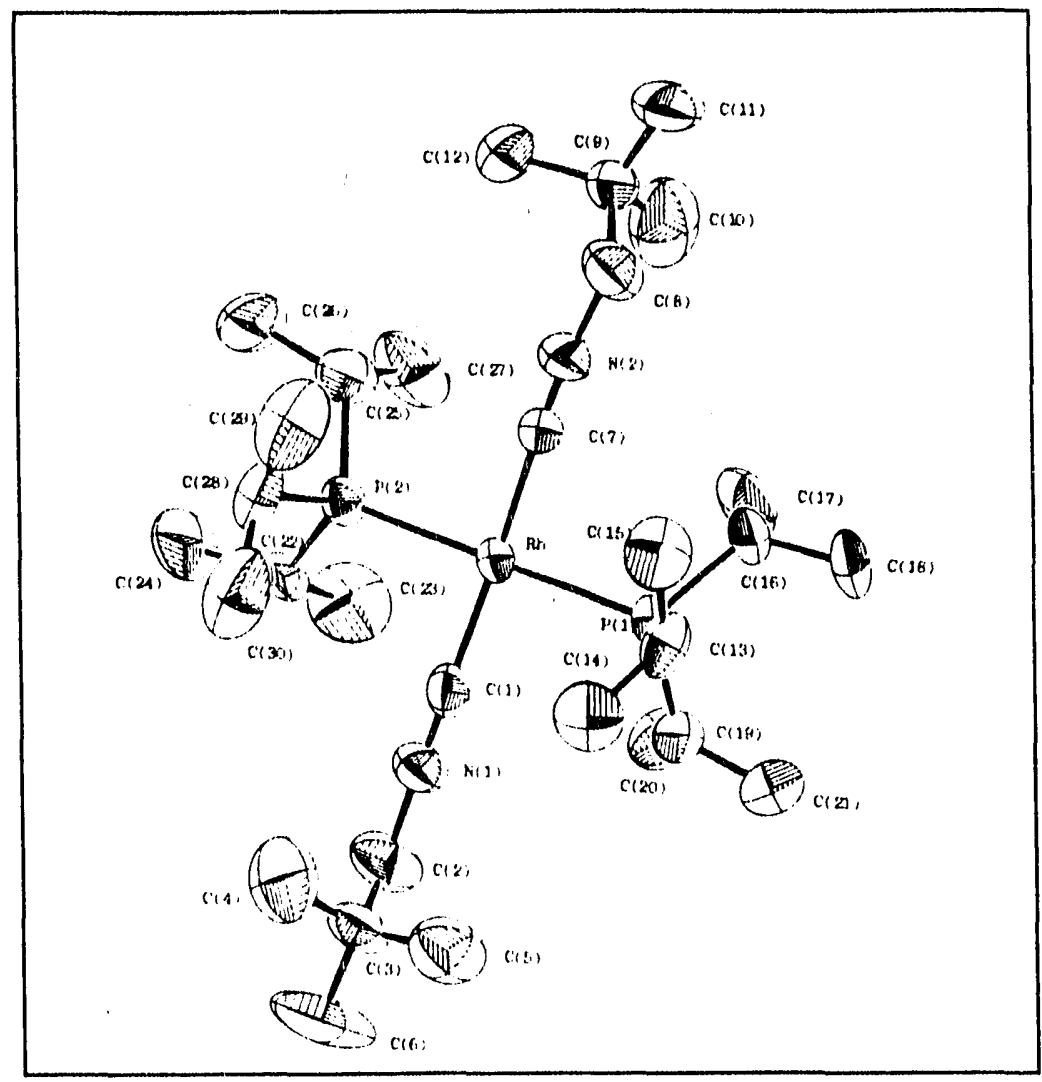

Figure 6. X-ray of $\left[\mathrm{Rh}\left(\mathrm{P}_{-} \mathrm{iPr}_{3}\right)_{2}\left(\mathrm{CNCH}_{2} \mathrm{CMe}_{3}\right)_{2}\right]^{+}$. 


\section{Pyrazolylborate Studies.}

Our earlier studies with $\left(\mathrm{C}_{5} \mathrm{Me}_{5}\right) \mathrm{Rh}(\mathrm{CNR})_{2}$ complexes indicated that they were inefficient (substoichiometric) in functionalizing aromatic $\mathrm{C}-\mathrm{H}$ bonds with isonitriles. ${ }^{7}$ The recent work in $\mathrm{C}-\mathrm{H}$ activation by Bill Graham using $\left(\mathrm{HBPz}_{3}{ }_{3}\right) \mathrm{Rh}(\mathrm{CO})_{2}$ complexes led us to investigate the reactions of the analogous bis isonitrile complexes.

The complexes $\left(\mathrm{HBPz}_{3}{ }_{3}\right) \mathrm{Rh}(\mathrm{CNR})_{2}$ where $\mathrm{R}=$ neopentyl and 2,6 -xylyl have been prepared. Structural characterization of these complexes revealed an unexfected feature. ${ }^{8}$ The trispyrazolylborate rings were $\eta^{2}$, not $\eta^{3}$ (Figure 7)! The rhodium prefers a 16-electron square planar geometry over an 18-electron trihapto geometry. An attempt to protonate the free pyrazole ligand led to protonation of the metal, inducing $\eta^{3}$ coordination of the tris-pyrazolylborate ligand to the newly formed cationic $\mathrm{Rh}$ (III) center (Figure 8).

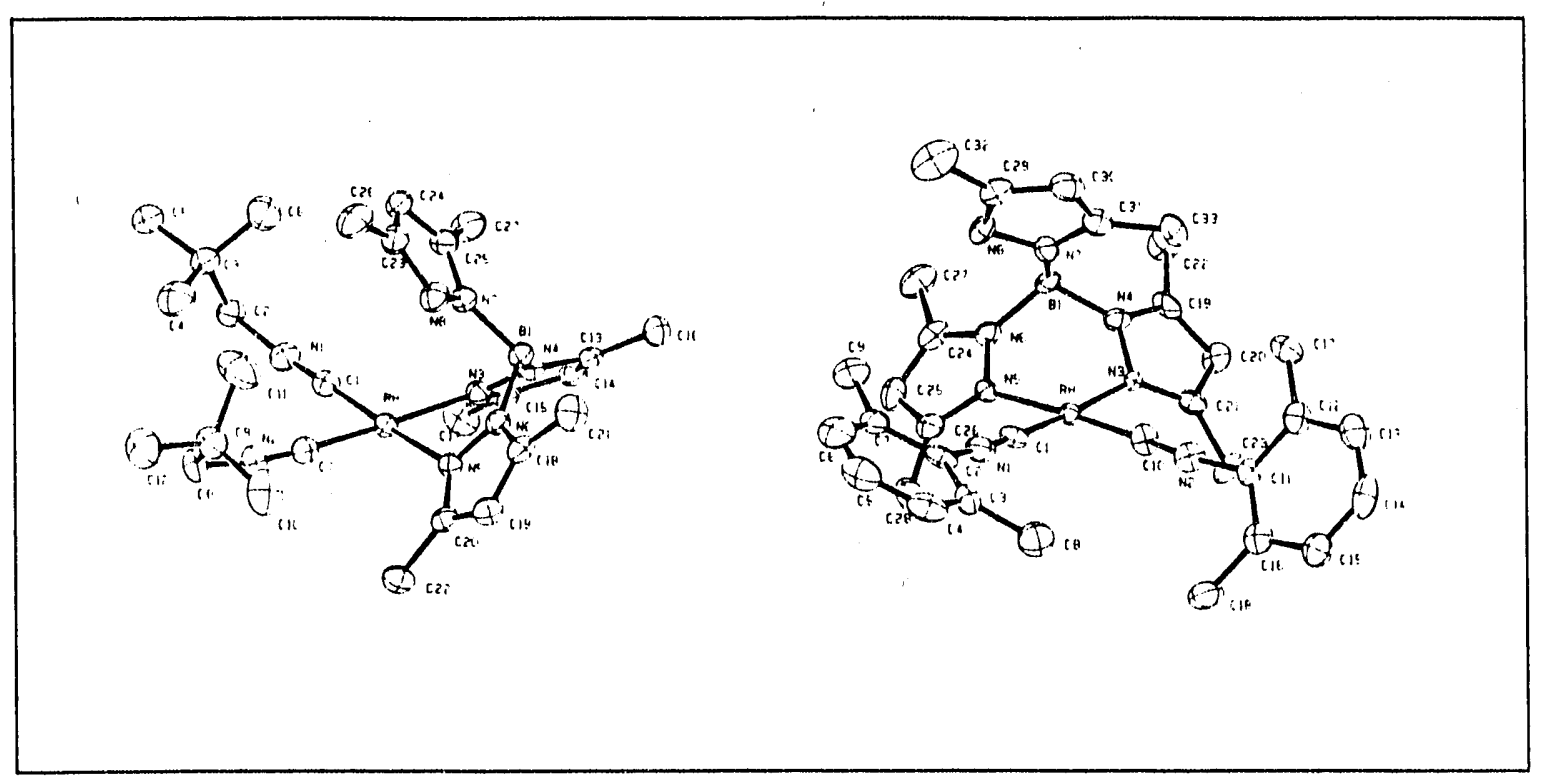

Figure 7. Xray of $\left(\mathrm{HBPz}_{3}{ }_{3}\right) \mathrm{Rh}\left(\mathrm{CNneopentyl}_{2}\right.$ and $\left(\mathrm{HBPz}_{3}{ }_{3}\right) \mathrm{Rh}(\mathrm{CNxylyl})_{2}$.

(7) Jones, W. D.; Feher, F. J. Organometallics, 1983, 2, 686-687.

(8) Jones, W. D.; Hessell, E. T. Inorr Chem. 1991, 30, 778-783. 


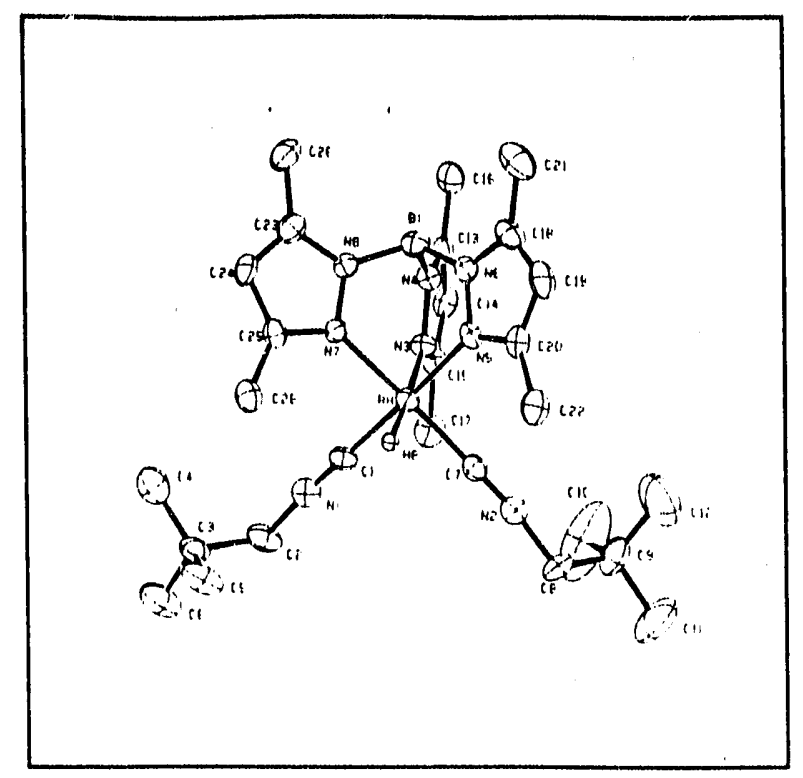

Figure 8. Xray of $\left[\left(\mathrm{HBPz}_{3}{ }_{3}\right) \mathrm{Rh}(\mathrm{CNneopentyl})_{2} \mathrm{H}\right]^{+}$.

Irradiation of the complexes in benzene solution slowly results in $\mathrm{C}-\mathrm{H}$ activation of the hydrocarbon solvent (Eq 3). ${ }^{9}$ In this case, the product is $\eta^{3}$ and the formation of an extra bond in the product makes the oxidative addition adduct quite stable. Benzene exchange with $C_{6} D_{6}$ is very sluggish, even at high temperatures. Attempts to force isonitrile insertion into the $\mathrm{Rh}-\mathrm{Ph}$ bond have failed, attesting to the stability of the $\eta^{3}$ adduct.

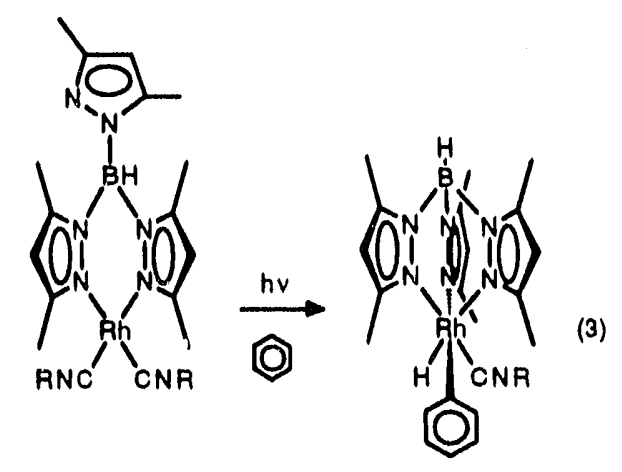

We have discovered that reaction of the bis-isocyanide complexes with phenyl azide $\left(\mathrm{PhN}_{3}\right)$ leads via $[1,3]$ dipolar addition to the new carbodiimide complexes (Eq 4). Irradiation of these compounds leads to the rapid and efficient loss of carbodiimide and

(9) Jones, W. D.; Duttweiler, R. P.; Feher, F. J.; Hessell, E. T. Nouv. J. Chem., 1989, 13, 725-736. 
activation of benzene solvent. ${ }^{10}$ Irradiation in alkane solvent also gives clean oxidative addition products. Some selectivities are given in Table IV. Comparison of the $[\mathrm{Tp} * \mathrm{Rh}(\mathrm{CNR})]$ fragment with $\left[\left(\mathrm{C}_{5} \mathrm{Me}_{5}\right) \mathrm{Rh}\left(\mathrm{PMe}_{3}\right)\right]$ shows the former to be slightly more selective.
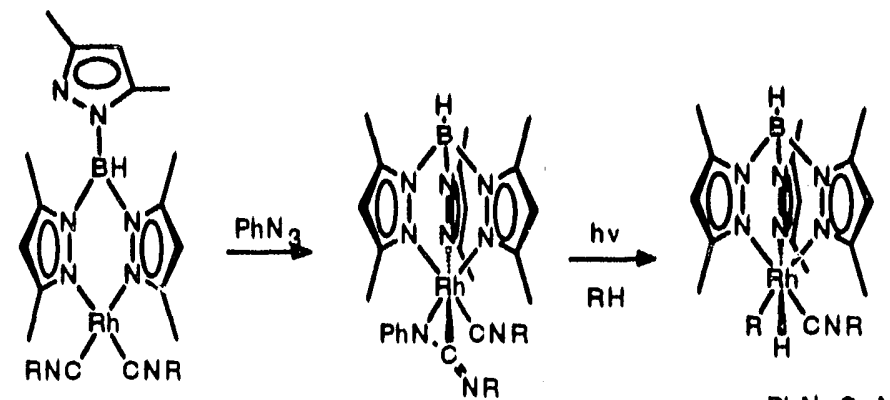

$+P h N=C=N R$

These oxidative addition reactions are reversible in the presence of added CNR. The rates appear to be first order in both rhodium complex and in CNR. Activation parameters are consistent with a bimolecular reaction. Several possible mechanisms are indicated in Scheme VII, all of which involve loss of benzene in or prior to the ratc: determining step with CNR.

Table IV. Preferences for alkane activation.

\begin{tabular}{|c|c|c|}
\hline substrate & $\begin{array}{c}\mathrm{k}_{\mathrm{m} !} \\
\mathrm{Tp} \mathrm{p}^{*} \mathrm{Rh}(\mathrm{CNR}) \\
\end{array}$ & $\begin{array}{c}\mathrm{k}_{\mathrm{rm} \mid} \\
\mathrm{Cp} \mathrm{R}^{*} \mathrm{Rh}\left(\mathrm{PMe}_{3}\right)\end{array}$ \\
\hline $\mathrm{C}_{6} \mathrm{H}_{12}$. & 1.0 & 1.0 \\
\hline $\mathrm{C}_{6} \mathrm{H}_{6}$ & 69 & 19.5 \\
\hline mesitylene, $1^{\circ}$ & 36 & - \\
\hline mesitylene, $2^{\circ}$ & 25 & - \\
\hline pentane, $1^{\circ}$ & 14.6 & 5.9 \\
\hline pentane, $2^{\circ}$ & 0 & 0 \\
\hline propane, $1^{\circ}$ & 14.6 & 2.6 \\
\hline propane, $2^{\circ}$ & 0 & 0 \\
\hline
\end{tabular}

(per $\mathrm{H}$, relative to $\mathrm{C}_{6} \mathrm{H}_{12}$ )

(10) Hessell, E. T.; Jones, W. D. Organometallics 1992, 11, 1496-1505. 


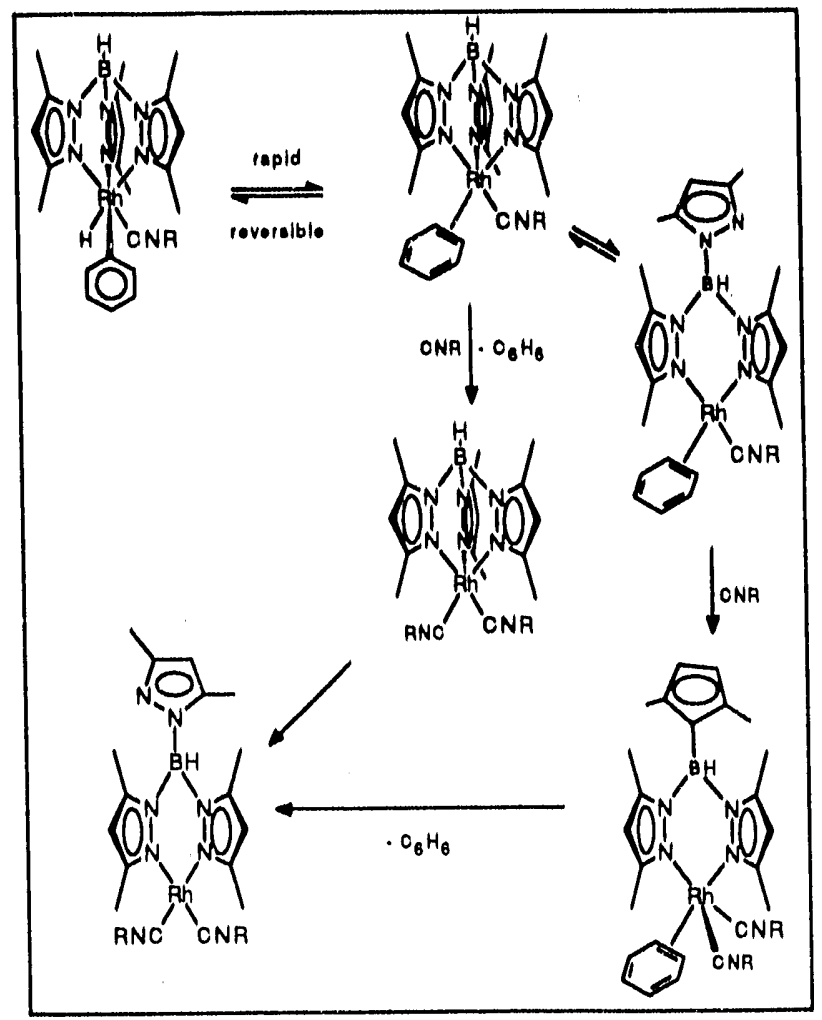

Scheme VII. Possible mechanisms for CNR induced elimination of benzene.

\section{Studies of $\left(\mathrm{C}_{5} \mathrm{Me}_{5}\right) \mathrm{Rh}\left(\mathrm{PMe}_{3}\right) \mathrm{H}_{2}$.}

The thermal chemistry of the dihydride complex $\left(\mathrm{C}_{5} \mathrm{Me}_{5}\right) \mathrm{Rh}\left(\mathrm{PMe}_{3}\right) \mathrm{H}_{2}$ has been examined in some detail, as it has been used extensively as a photochemical precursor of the 16-electron intermediate $\left[\left(\mathrm{C}_{5} \mathrm{Me}_{5}\right) \mathrm{Rh}\left(\mathrm{PMe}_{3}\right)\right]$. Initially, the barrier to thermal reductive elimination of $\mathrm{H}_{2}$ from $\left(\mathrm{C}_{5} \mathrm{Me}_{5}\right) \mathrm{Rh}\left(\mathrm{PMe}_{3}\right) \mathrm{H}_{2}$ was to be measured by monitoring the exchange with $\mathrm{D}_{2}$. However, it was soon discovered that while the exchange reaction proceeded readily at $25^{\circ} \mathrm{C}$, the intermediate species $\left(\mathrm{C}_{5} \mathrm{Me}_{5}\right) \mathrm{Rh}\left(\mathrm{PMe}_{3}\right) \mathrm{HD}$ could be detected by ${ }^{31}$ P NMR spectroscopy (Figure 9) prior to the formation of $\left(\mathrm{C}_{5} \mathrm{Me}_{5}\right) \mathrm{Rh}\left(\mathrm{PMe}_{3}\right) \mathrm{D}_{2}$. The stepwise exchange of deuterium was clearly inconsistent with the reductive elimination mechanism, and so the details of the mechanism of the reaction were investigated."1

(11) Jones, W. D.; Chandler, V. L.; Selmeczy, A. D. Organometallics, 1991, 10, 1577-1586. 


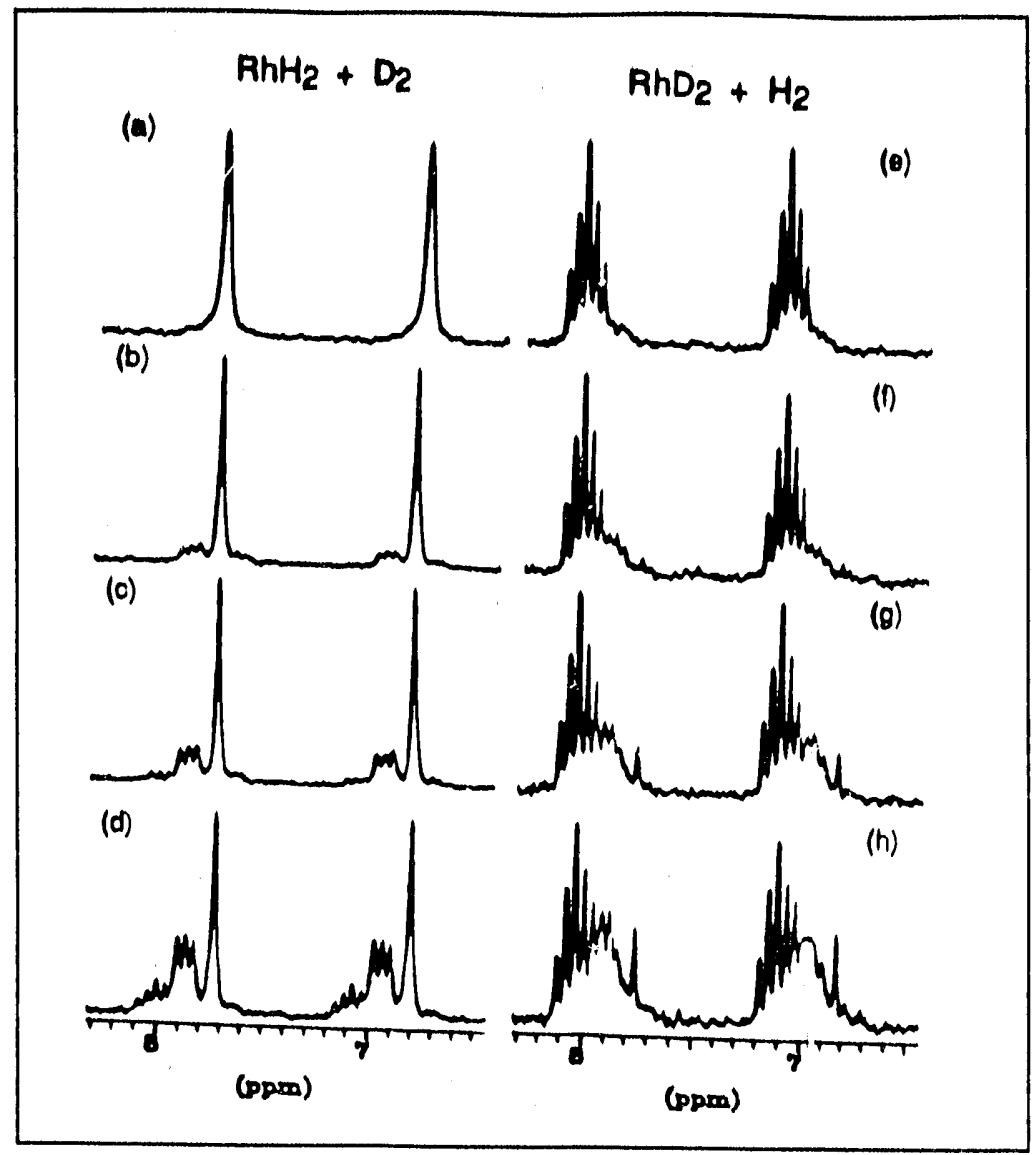

Figure 9. ${ }^{31} \mathrm{P} \mathrm{NMR}$ of $\left(\mathrm{C}_{5} \mathrm{Me}_{5}\right) \mathrm{Rh}\left(\mathrm{PMe}_{3}\right) \mathrm{HD}$.

The kinetics of the reaction were monitured as a function of $D_{2}$ pressure, the exchange following pseudo first order kinetics. A linear dependence on $\left[D_{2}\right]$ was observed, indicating a bimolecular mechanism. Under 1 atm of $D_{2}$, the exchange reaction has a half life of only a few hours at RT. Two possible mechanisms were proposed, one involving initial $\eta^{5} \longrightarrow \eta^{3}$ ring slippage and a second involving metal to ring hydride migration. In both cases, a 16- electron metal complex is formed that then undergoes oxidative addition of $\mathrm{D}_{2}$ (Scheme VIII).

In an effort to trap out the unsaturated intermediate in the reaction, $\mathrm{PMe}_{3}$ was added to the sample to produce a coordinatively saturated species. Reaction does occur at a reasonable rate, but only upon heating to $40{ }^{\circ} \mathrm{C}$. However, it was found that $\mathrm{PMe}_{3}$ not only coordinates to the vacant site but also induces complete elimination of the $\mathrm{C}_{5} \mathrm{Me}_{5} \mathrm{H}$ ring ( $\mathrm{Eq} 5$ ). The rate of this reaction was also measured as a function of 
$\left[\mathrm{PMe}_{3}\right]$, but now it was found that the rate saturated when $\left[\mathrm{PMe}_{3}\right]>0.2 \mathrm{M}$, suggesting a reversible, unimolecular pre-equilibrium followed by a rate determining reaction with $\mathrm{PMe}_{3}$. These results can again be interpreted in terms of either a ring slippage or hydride migration mechanism (Scheme IX).

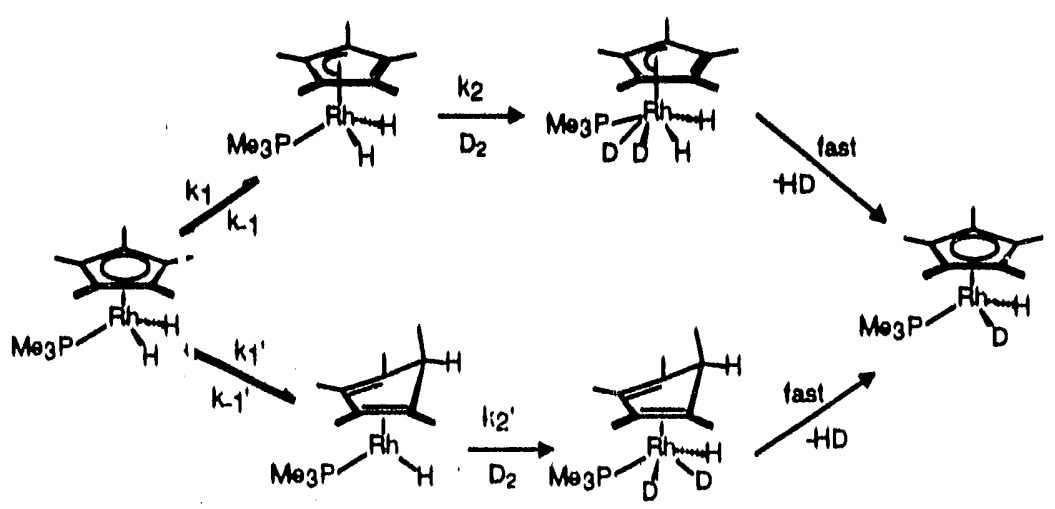

Scheme VIII. Ring slip and hydride migration mechanisms for H/D exchange.

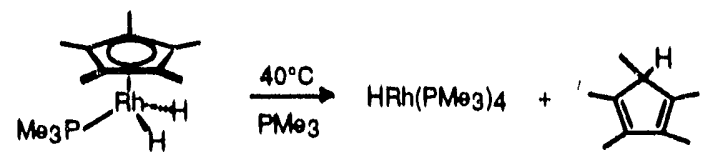

Isotope studies on the $\mathrm{PMe}_{3}$ reaction showed no difference in rate when either $\left(\mathrm{C}_{5} \mathrm{Me}_{5}\right) \mathrm{Rh}\left(\mathrm{PMe}_{3}\right) \mathrm{H}_{2}$ or $\left(\mathrm{C}_{5} \mathrm{Me}_{5}\right) \mathrm{Rh}\left(\mathrm{PMe}_{3}\right) \mathrm{D}_{2}$ were used. This result leads to the belief that the $\mathrm{PMe}_{3}$ reaction in Eq 5 proceeds by an $\eta^{5} \rightarrow \eta^{3}$ ring slip followed by rate determining coordination of $\mathrm{PMe}_{3}$ (Scheme IX, top). However, the reaction of $\left(\mathrm{C}_{5} \mathrm{Me}_{5}\right) \mathrm{Rh}\left(\mathrm{PMe}_{3}\right) \mathrm{H}_{2}$ with $\mathrm{D}_{2}$ at this temperature is already much faster than the rate limiting ring slip step of the reaction, indicating that the $H / D$ exchange reaction must be occurring by a different pathway. Consequently, the $\mathrm{H} / \mathrm{D}$ exchange is believed to occur by way of initial hydride to ring migration, Scheme VIII, bottom.

It is interesting to note that two independent mechanisms of reaction must be operating with $\left(\mathrm{C}_{5} \mathrm{Me}_{5}\right) \mathrm{Rh}\left(\mathrm{PMe}_{3}\right) \mathrm{H}_{2}$, and that neither of these was the anticipated unimolecular reductive elimination of dihydrogen! 


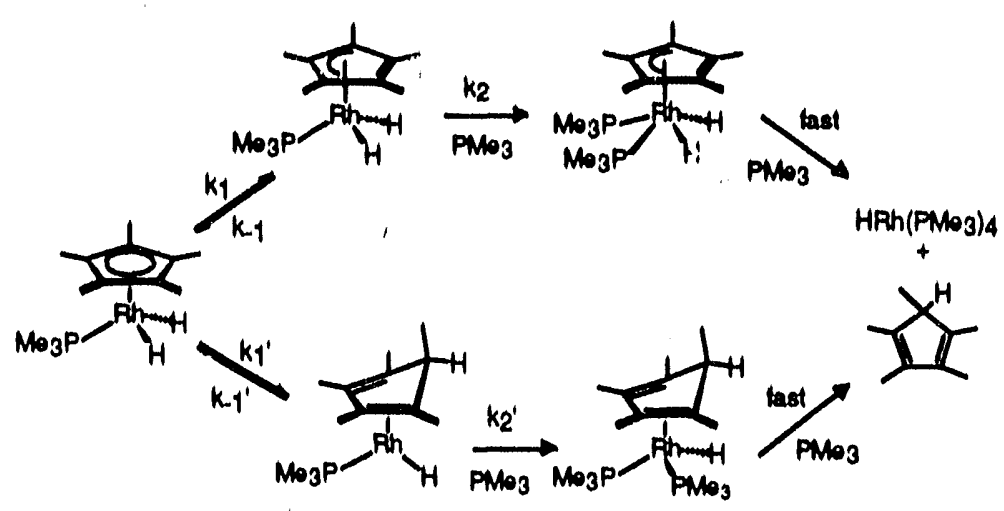

Scheme IX. Ring Slip and Hydride migration mechanisms for $\mathrm{PMe}_{3}$ reaction.

\section{Effects of Phosphine on $\left(\mathrm{C}_{5} \mathrm{Me}_{5}\right) \mathrm{Rh}\left(\mathrm{PR}_{3}\right) \mathrm{PhH}$ Stability.}

The series of complexes $\left(\mathrm{C}_{5} \mathrm{Me}_{5}\right) \mathrm{Rh}\left(\mathrm{PR}_{3}\right) \mathrm{PhH}$ where $\mathrm{PR}_{3}=\mathrm{PMe}_{3}, \mathrm{PMe}_{2} \mathrm{Ph}$, $\mathrm{PMePh}_{2}$, and $\mathrm{PPh}_{3}$ have been prepared from the corresponding bromo complexes and their oxidative addition/reductive elimination chemistry has been probed. X-ray structures of all the phenyl bromide complexes have been determined, and each shows a nearly identical orientation of the phosphine and the phenyl group with respect to rotation about the Rh-P and Rh-Th bonds (Figure 10).

Upon dissolving these species in $\mathrm{C}_{6} \mathrm{D}_{6}$ at $25^{\circ} \mathrm{C}$, the rate of benzene loss can be measured by monitoring the first order rate of formation of $\left(\mathrm{C}_{5} \mathrm{Me}_{5}\right) \mathrm{Rh}\left(\mathrm{PR}_{3}\right)\left(\mathrm{C}_{6} \mathrm{D}_{5}\right) \mathrm{D}$. Rate constants are given in Table V, showing that replacement of methyl groups by phenyl groups results in an increase in the rate of benzene loss. Since either steric and/or electronic factors could explain this rate increase, the elimination rates of complexes of several other phosphines were also examined. Both steric and electronic effects were found to be influential, although the latter was found to be of greater importance. 

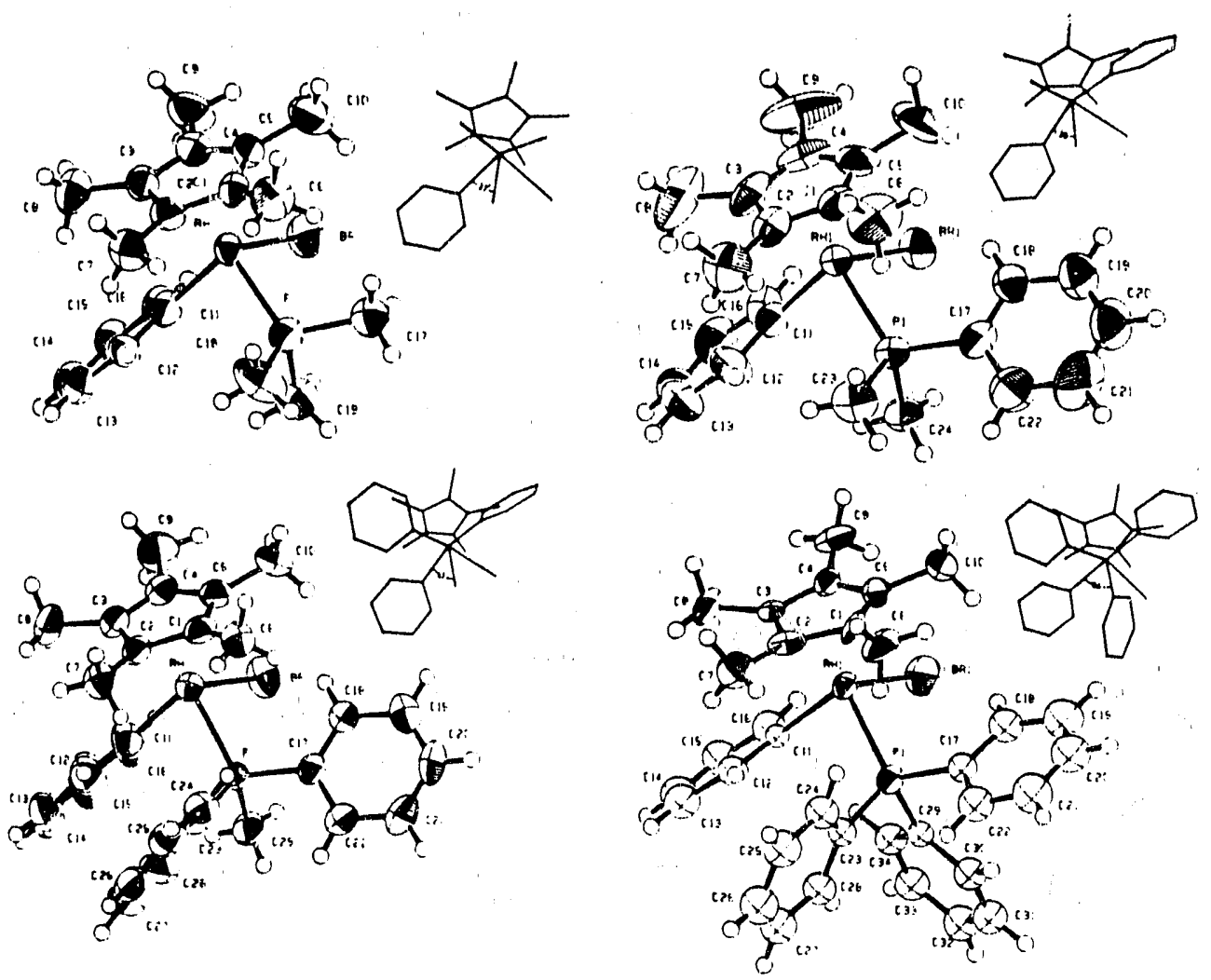

Figure 10. ORTEP drawings of $\left(C_{5} M e_{5}\right) R h\left(P R_{n} R_{3-n}^{\prime}\right) P h B r$ complexes $\left(R=M e, R^{\prime}=P h, n=0-3\right)$.

Table 5. Rates of Benzene Loss from $\left(\mathrm{C}_{5} \mathrm{Me}_{5}\right) \mathrm{Rh}\left(\mathrm{PR}_{3}\right)\left(\mathrm{C}_{6} \mathrm{D}_{5}\right) \mathrm{D}$ Complexes

\begin{tabular}{ccccc}
$\mathrm{PR}_{3}$ & Cone Angle & $\mathrm{T}\left({ }^{\circ} \mathrm{C}\right)$ & $\mathrm{k}, \mathrm{s}^{-1}$ & $\Delta \mathrm{G}^{\ddagger}, \mathrm{Kcal} / \mathrm{mole}$ \\
\hline $\mathrm{PMe}_{3}$ & 118 & 23 & $3.35(17) \times 10^{-7}$ & 26.1 \\
$\mathrm{PMe}_{2} \mathrm{Ph}$ & 122 & 23 & $1.08(5) \times 10^{-6}$ & 25.4 \\
$\mathrm{PMePh}_{2}$ & 136 & 24.5 & $1.11(6) \times 10^{-5}$ & 24.2 \\
$\mathrm{PPh}_{3}$ & 145 & 23 & $3.85(19) \times 10^{-4}$ & 21.9 \\
$\mathrm{PMe}_{2}(\mathrm{t}-\mathrm{Bu})$ & 139 & 24.5 & $6.6(3) \times 10^{-6}$ & 24.5 \\
$\mathrm{PMe}_{2}(\mathrm{n}-\mathrm{Bu})$ & 123 & 24.5 & $1.25(3) \times 10^{-5}$ & 24.1 \\
$\mathrm{P}(\mathrm{n}-\mathrm{Bu})_{3}$ & 132 & 24.5 & $2.4(1) \times 10^{-6}$ & 25.1
\end{tabular}




\section{C-H Activation by Rhenium and Manganese.}

Several new manganese and rhenium complexes have been prepared that activate $\mathrm{C}-\mathrm{H}$ bonds. These include $\mathrm{Re}(\mathrm{dmpe})_{2} \mathrm{H}_{3}$ and $\mathrm{Mn}(\mathrm{dmpe})_{2} \mathrm{H}_{3}$. The manganese complex is believed to be a dihydrogen complex, based upon its low $\mathrm{T}_{1}\left(30 \mathrm{~ms}\right.$ at $\left.-70^{\circ} \mathrm{C}\right)$, its ease of oxidation $\left(E_{1 / 2}=-0.85 \mathrm{~V}\right.$ vs $\left.\mathrm{NHE}\right)$, the facile formation of an $\mathrm{N}_{2}$ complex, and the lability of the $\mathrm{H}_{2}$ ligand. A variety of substituted derivatives have been prepared of the ty $y_{1}$ e $\mathrm{Mn}(\mathrm{dmpe})_{2} \mathrm{HL}\left(\mathrm{L}=\mathrm{CNR}, \mathrm{CO}, \mathrm{C}_{2} \mathrm{H}_{4}, \mathrm{~N}_{2}\right)$, all of which have similar facile oxidation potentials. The trihydride complex readily exchanges hydrogen for deuterium upon warming in $\mathrm{C}_{6} \mathrm{D}_{6}$ solution. Eventually, even the dmpe ligands become deuterated. Addition of alkanes to the solution shows no evidence for alkane deuteration, although toluene will undergo exchange of its benzylic hydrogens.

The rhenium trihydride complex shows enhanced reactivity. Heating this complex to $150^{\circ} \mathrm{C}$ or irradiating with near UV light results in $\mathrm{H} / \mathrm{D}$ exchange chemistry similar to that of the manganese complex. The rhenium complex, however, will also catalyse H/D exchange with alkanes, showing a kinetic high selectivity for terminal $\mathrm{C}-\mathrm{H}$ bonds. While no intennediates are detected in this reaction, a mechanism involving reversible $\mathrm{H}_{2}$ loss, $\mathrm{C}_{6} \mathrm{D}_{6}$ oxidative addition, $\mathrm{C}_{6} \mathrm{D}_{5} \mathrm{H}$ reductive elimination, alkane oxidative addition, and alkane- $d_{1}$ reductive elimination would readily account for the observations $\left(\operatorname{Re}^{l} / \operatorname{Re}^{\text {III }}\right.$ couple). Further studies of substituted derivatives $\mathrm{R} r(\mathrm{dmpe})_{2} \mathrm{HL}\left(\mathrm{L}=\mathrm{CO}, \mathrm{C}_{2} \mathrm{H}_{4}, \mathrm{CNR}\right)$ are underway for comparison with the manganese system.

\section{Rhenium Indenyl Chemistry.}

Earlier studies in our lab showed that $\mathrm{CpRe}\left(\mathrm{PPh}_{3}\right)_{2} \mathrm{H}_{2}$ could act as an efficient photocatalyst for $H / D$ exchange between alkanes and $C_{6} D_{6}$. In an effort to prepare a thermal catalyst for this exchange, we prepared the related indenyl complex. The chemistry involved in the preparation proved to be rather interesting, and seven new compounds were synthesized simply by varying the reaction conditions. 
The basic reaction involves the thermoiysis of $\operatorname{Re}\left(\mathrm{PPh}_{3}\right)_{2} \mathrm{H}_{7}$ in the presence of indene. This reaction was found to give the anticipated indenyl complex (Ind) $\mathrm{Re}\left(\mathrm{PPh}_{3}\right)_{2} \mathrm{H}_{2}$ as the minor product with a complex $\eta^{5}$ bound to the 6-membered ring as the major product. Further studies showed that addition of $t$-butylethylene to the reaction mixture led to the efficient production of the indenyl complex, whereas running the reaction under an atmosphere of $\mathrm{H}_{2}$ gave exclusively the $\eta^{5}$-6-membered ring product. Scheme $\mathrm{X}$ shows the mechanism proposed for these observations. Other related complexes were prepared by using partially hydrogenated indene derivatives such as indan instead of indene. These are summarized in Scheme XI.

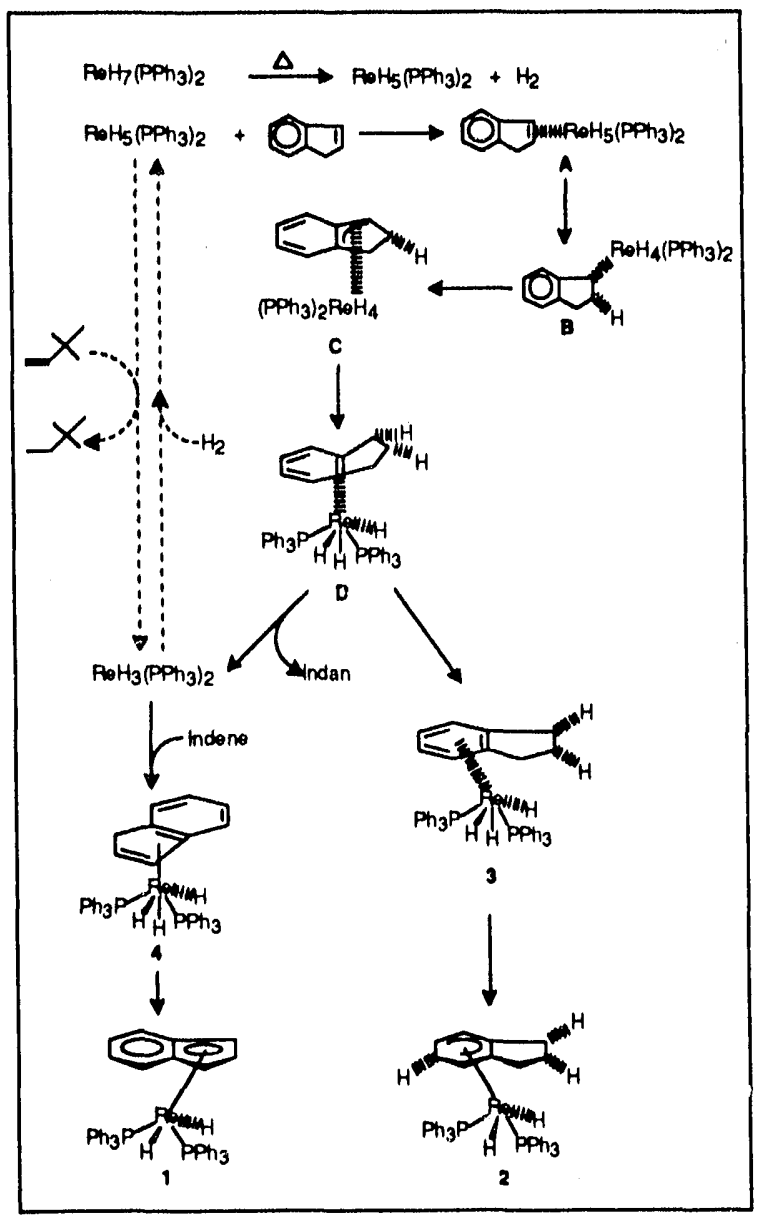

Scheme X. Mechanism of formation of indene derivatives 


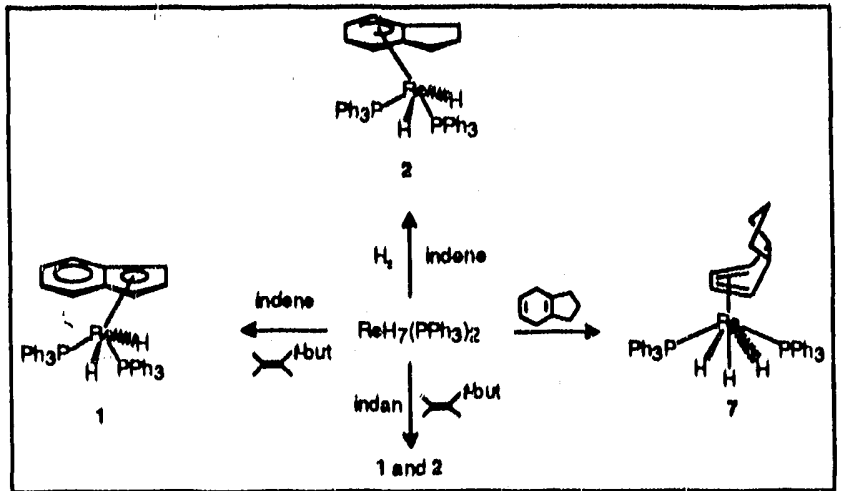

Scheme XI. Indene derivatives produced from $\operatorname{Re}(\mathrm{PPh} 3)_{2} \mathrm{H}_{7}$. 


\section{B. Summary and Further Studies}

In summary, the chemistry of a variety of rhodium complexes has been explored with regard to their fundamental interactions with hydrocarbons and heterocycles, their ability to functionalize $\mathrm{C}-\mathrm{H}$ bonds, and their mechanisms of reactions. In the renewal of this grant, we will continue to develop the themes of these studies in addition to the addition of new areas of research. To receive special attention will be:

1. The factors that control the stability of $\eta^{2}$-arene complexation relative to $\mathrm{C}-\mathrm{H}$ bond activation. Knowledge of these factors will lead to better predictive ability for the reaction of a given hydrocarbon or functionalized species with a low valent metal center.

2. The functionalization of $\mathrm{C}-\mathrm{H}$ bonds with small molecules. We will examine the reactions of oxidants with a number of the complexes that have already been shown to activate alkane $\mathrm{C}-\mathrm{H}$ bonds, with the goal of producing alcohols or higher oxidation products under mild conditions in mind. While isonitriles are thermodynamically capable of catalytically functionalizing hydrocarbons, we have found them to be kinetically slow since the metal-isocyanide complexes tend to sit in deep wells. The use of sterically more encumbered isocyanides should destabilize these $\sigma$-complexes due to unfavorable steric interactions. Ligands such as $\mathrm{CNC}(t-\mathrm{Bu})_{3}$ or $\mathrm{CNSi}(t-\mathrm{Bu})_{3}$, or $\mathrm{CN}($ adamantyl $)$ will be examined. Additionally, the use of $\mathrm{CO}$ and ethylene (together) for functionalization will be probed.

3. We will examine the reactions of other common X-H functionalities with $\mathrm{C}-\mathrm{H}$ bond activation catalysts, for comparison of their reactivity.

4. We will examine new complexes for $\mathrm{C}-\mathrm{H}$ bond functionalization, including several of the rhenium complexes that have been under study for the past few years in our group, such as $\mathrm{RuH}_{2}(\mathrm{dmpe})_{2}$, (Ind) $\mathrm{Re}\left(\mathrm{PPh}_{3}\right)_{2} \mathrm{H}_{2}$ and $\mathrm{CpRe}\left(\mathrm{PMe}_{2} \mathrm{Ph}\right)_{2} \mathrm{H}_{2}$. 


\section{Publications}

The work under DOE support has been published in the following articles:

1. "Mechanism of Arene $\mathrm{C}-\mathrm{H}$ Bond Activation by $\left[\mathrm{C}_{5}\left(\mathrm{CH}_{3}\right)_{5}\right] \mathrm{Rh}\left[\mathrm{P}\left(\mathrm{CH}_{3}\right)_{3}\right](\mathrm{H})\left(\mathrm{C}_{6} \mathrm{H}_{5}\right)$. Evidence for Arene Precoordination", William D. Jones and Frank J. Feher, J. Am. Chem. Soc. 1982, 104, 4240. 4242.

2. "Preparation and Reactions of New Isocyanide Complexes of Rhodium and Their Rcie in CarbonHydrogen Bond Activation", William D. Jones and Frank J. Feher, Organometallics 1983, 2, 686687.

3. "Alkane Carbon-Hydrogen Bond Activation by Homogeneous Rhodium(I) Compounds", William D. Jones and Frank J. Feher, Organometallics 1983, 2, 562-563.

4. "Preparation and Conformational Dynamics of $\left(\mathrm{C}_{5} \mathrm{Me}_{5}\right) \mathrm{Rh}\left(\mathrm{PR}_{3}\right) \mathrm{RX}$. Hindered Rotation about Rhodium-Phosphorus and Rhodium-Carbon Bonds", William D. Jones and Frank J. Feher, Inorg. Chem. 1984, 23, 2376-2388.

* 5. "The Mechanism and Thermodynamics of Alkane and Arene Carbon-Hydrogen Bond Activation in $\left(\mathrm{C}_{5} \mathrm{Me}_{5}\right) \mathrm{Rh}\left(\mathrm{PMe}_{3}\right)(\mathrm{R}) \mathrm{H}$ ", William D. Jones and Frank J. Feher, J. Am. Chem. Soc. 1984, 106, 16501663.

* 6. "Kinetics and Thermodynamics of Intra- and Intermolecular Carbon-Hydrogen Bond Activation." William D. Jones and Frank J. Feher, J. Am. Chem. Soc. 1985, 107, 620-631.

7. "The Mechanism and Thermodynamics of $\mathrm{C}-\mathrm{H}$ bond Activation by Complexes of Rhodium", William D. Jones and Frank J. Feher, Proceedings of the 4th International Symposium on Homogeneous Catalysis, Leningrad, USSR : Gordon and Breach Science Publishers, Inc., New York (1984), vol. 3 , pp. 973-984.

* 8. "Preparation and Reaction Dynamics of $\left(\eta^{4}-\mathrm{C}_{5} \mathrm{H}_{6}\right) \mathrm{Re}\left(\mathrm{PPh}_{3}\right)_{2} \mathrm{H}_{3}$. A Structurally Characterized $\eta 4$ Cyclopentadiene Complex", William D. Jones and John A. Maguire, Organometallics 1985, 4, 951 953.

* 9. "The Direct Intermolecular Transfer of Dihydrogen Between Two Transition Metal Complexes," William D. Jones and John A. Maguire, J. Am. Chem. Soc. 1985, 107, 4544-4547.

10. "The Mechanism and Thermodynamics of C-H Bond Activation by Complexes of Rhodium", Proceedings of the Gas Research Institute Workshop on Basic Research Opportunities in Methane Activation Chemistry, pp. 23-27, Feb. 4-6, 1985, Houston, Texas. Arthur D. Little, publisher.

* 11. "Preparation and Structural Comparison of the Ruthenium(0) Derivatives $R u(d m p e){ }_{2} L\left(L=P M c_{3}\right.$, CO; DMPE = 1,2-Bis(dimethylphosphino)ethane)", William D. Jones and Emanuela Libertini, Inorg. Chem. 1986, 25, 1794-1800.

* 12. "The Activation of Methane by Rhenium. Catalytic H/D Exchange in Alkanes with $\mathrm{CpRe}\left(\mathrm{PPh}_{3}\right)_{2} \mathrm{H}_{2}$ ", William D. Jones and John A. Maguire, Organometallics 1986, 5, 590-591.

13. "Homogeneous Alkane Activation", William D. Jones, Recent Advances in Alkane Activation; Catalytica Associates, Publisher: Mountain View, California, 1986. pp.5-168. 
* 14. "Isotope Effects in Arene C-H Bond Activation by $\left[\left(\mathrm{C}_{5} \mathrm{Me}_{5}\right) \mathrm{Rh}\left(\mathrm{PMe}_{3}\right)\right]$ ", William D. Jones and Frank I. Feher, J. Am. Chem. Soc. 1986, 108, 4814-4819.

* 15. "Preparation and C-N Cleavage Reactions of Bis(dimethylphosphinoethane)Ruthenium Isocyanide Complexes", William D. Jones and Walter P. Kosar, Organometallics 1986, 5, 1823-1829.

* 16. "Activation of C-H Bonds by Rhenium. Catalytic Intermolecular H/D Exchange with $\left(\eta^{6-} \mathrm{C}_{6} \mathrm{H}_{6}\right) \operatorname{Re}\left(\mathrm{PPh}_{3}\right)_{2} \mathrm{H}^{\prime \prime}$, William D. Jones and Mingxin Fan, Organometallics 1986, 5, 1057-1059.

* 17. "Carbon-Hydrogen Bond Activation for the Catalytic Synthesis of Indoles", William D. Jones and Walter P. Kosar, J. Am. Chem. Soc. 1986, 108, 5640-5641.

** 18. "Preparation, Dynamic Behavior, and C-H and C-C Cleavage Reactions of $\left(\eta^{4}-\mathrm{C}_{5} \mathrm{H}_{6}\right) \mathrm{Re}\left(\mathrm{PPh}_{3}\right)_{2} \mathrm{H}_{3}$. Structures of $\left(\eta^{4}-\mathrm{C}_{5} \mathrm{H}_{6}\right) \mathrm{Re}\left(\mathrm{PPh}_{3}\right)_{2} \mathrm{H}_{3}, \mathrm{CpRe}\left(\mathrm{PPh}_{3}\right)_{2} \mathrm{H}_{2}$, and $\mathrm{CpRe}\left(\mathrm{PPh}_{3}\right) \mathrm{H}_{4}{ }^{\prime \prime}$, William D. Jones and John A. Maguire, Organometallics 1987, 6, 1301-1311.

** 19. "Synthesis, Structures, and C-H Bond Activation Reactions of $\mathrm{HRe}\left(\mathrm{PR}_{3}\right)_{2}(\mathrm{~L})_{3}$ Complexes", William D. Jones and John A. Maguire, Organometallics 1987, 6, 1728.1737.

20. "Dihydride Transfer. A Bimolecular Mechanism in the Isomerization of cisDihydridobromo(carbonyl)-(bis(diphenylphosphino)ethane)iridium, $\operatorname{IrH}_{2} \mathrm{Br}(\mathrm{CO})$ (dppe)", Amanda J. Kunin, Curtis E. Johnson, John A. Maguire, William D. Jones, and Richard Eisenberg, J. Am. Chem. Soc. 1987, 109, 2963-2968.

** 21. "Preparation and Structural Examination of a Series of New, Low-Valent Iron Phosphine Isonitrile Complexes with Bent C-N-C Linkages.", William D. Jones, Glenn P. Foster, and Jeanne M. Putinas, Inorg. Chem., 1987, 26, 2120-2127.

** 22. "Chemical and Electrocatalytic Oxidation of $\mathrm{CpRe}\left(\mathrm{PAr}_{3}\right)_{2} \mathrm{H}_{2}$ Complexes To Give Stable 17-Electron Radical Cations. Disproportionation to Diamagnetic Species via Electron-Transfer Catalysis," Michael R. Detty and William D. Jones, J. Am. Chem. Soc. 1987, 109, 5666-5673.

** 23. "The Catalytic Activation and Functionalization of $\mathrm{C}-\mathrm{H}$ Bonds. Aldimine Formation by the Insertion of Isonitriles into Aromatic C-H Bonds", William D. Jones, Glenn P. Foster, and Jeanne M. Putinas, J. Am. Chem. Soc. 1987, 109, 5047-5048.

24. "Alkane Activation by Processes by Cyclopentadienyl Complexes of Rhodium, Iridium, and Related Species," William D. Jones, Chapter 4 in Activation and Functionalization of Alkanes, Craig Hill, Ed., John Wiley and Sons, New York, 1989, pp.111-149.

** 25. "Comparative Reactivities of Hydrocarbon C-H Bonds With a Transition-Metal Complex," William D. Jones and Frank J. Feher, Acc. Chem. Res. 1989, 22, 91 - 100.

26. "Development of Catalytic Processes for trie Synthesis of Organic Compounds that Involve C-H Bond Activation," William D. Jones, Chapter 5 in Selective Hydrocarbon Activation, P. L. Watson, Ed., VCH Publishers, Toledo, OH, pp. 113-148.

27. "Organometallic Transformations via C-H Bond Activation", William D. Jones, Valerie L. Chandler, Robert P. Duttweiler, Frank J. Feher, Edward T. Hessell, Grace C. Hsu, and Walter P. Kosar, Organometallics in Organic Synthesis, Aspects of a Modern Interdisciplinary Field, Proceedings of the Second Symposium on Organic Synthesis via Organometallics, H. Werner \& G. Erker, Eds., Würzburg, FRG, October 19-22, Springer-Verlag, Heidelberg (1988), pp.185-201. 
28. "Hydride Abstraction. The Reaction of IrX(CO)(dppe) with $\mathrm{Cp}_{2} \mathrm{TaH}_{3}$," Paul J. Deutsch, John A. Maguire, William D. Jones, and Richard Eisenberg, Inorg. Chem. 1990, 29, 686-690.

*** 29. "Isonitrile Insertion into Activated C-H Bonds Using $\left(\mathrm{C}_{5} \mathrm{Me}_{5}\right) \mathrm{ML}_{2}$ Complexes and Analogs," William D. Jones, Robert P. Duttweiler, Jr., Frank J. Feher, and Edward T. Hessell, Nouv. J. Chem. $1989,13,725-736$.

*** 30. "Preparation and Characterization of $\left(\mathrm{C}_{5} \mathrm{Me}_{5}\right) \mathrm{Rh}(\mathrm{CNK})_{2}$ and $\left[\left(\mathrm{C}_{5} \mathrm{Me}_{5}\right) \mathrm{Rh}(\mathrm{CNR})\right]_{2}$ Complexes," William D. Jones, Robert P. Duttweiler, Jr., and Frank J. Feher, Inorg. Chem. 1990, 29, 1505-1511.

*** 31. "Reactions of $\left(\mathrm{C}_{5} \mathrm{Me}_{5}\right) \mathrm{Rh}\left(\mathrm{PMe}_{3}\right)(\mathrm{R}) \mathrm{H}$ with Electrophiles. The Insertion of Unsaturated Molecules into Activated Carbon-Hydrogen Bonds", William D. Jones, Valerie L. Chandler, and Frank J. Feher, Organometallics 1990, 9, 164-174.

*** 32. "Direct Obervation of $\eta^{2}$-Areme Complexes of $\left[\left(\mathrm{C}_{5} \mathrm{Me}_{5}\right) \mathrm{Rh}\left(\mathrm{PMe}_{3}\right)\right]$," William D. Jones and Lingzhen Dong, J. Am. Chem. Soc, 1989, 111, 8722-8723.

*** 33. "Catalytic Functionalization of $\mathbb{C}-\mathrm{H}$ Bonds by Isonitrile Insertion. Preparation, Characterization, and Reactivity of $\mathrm{RhCl}\left(\mathrm{PR}_{3}\right)_{2}(\mathrm{CNTR})$." William D. Jones and Edward P. Hessell, Organometallics 1990 , 9, 718-727.

***: 34. "New Square Planar Complexes of Rhodium and Their Reactions with C-H Bonds," William D. Jones and Edward T. Hessell, Nouv. J. Chem. 1990, 14, 481-485.

*** 35. "Insertion of Rhodium into the Carbon-Sulfur Bond of Thiophene. Mechanism and Thermodynamics of a Model for the Hydrodesulfurization (HDS) Reaction," William D. Jones and Lingzhen Dong, $J$. Am. Chem. Soc. 1991, 113, 559-564.

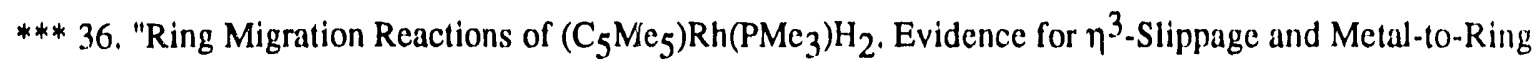
Hydride Migration," William D. Jones, Valerie L. Kuykendall, and Anthony D. Selmeczy, Organometallics 1991, 10, 1577-1586.

*** 37. "Synthesis and Structures of Some Rhodium Isocyanide Complexes Containing an $\eta^{2}$. Hydridotris(3,5-dimethylpyrazolyl)borate Ligand," William D. Jones and Edward T. Hessell, Inorg. Chem. 1991, 30, 778-783.

*** 38. "Control of $\eta^{2}$-Arene Coordination and C-H Bond Activation by Cyclopentadienyl Complexes of Rhodium", Simon T. Belt, Lingzhen Dong, Simon B. Duckett, William D. Jones, Martin G. Partridge, and Robin N. Perutz, J. Chem. Soc., Chem. Commun. 1991, 266-269.

*** 39. "Sequential Arene Coordination and C-F Insertion in the Reactions of ( $\eta^{5}$ - Cyclopentadienyl)rhodium Complexes with $\mathrm{C}_{6} \mathrm{~F}_{6}$ ", William D. Jones, Martin G. Partridge, and Robin N. Perutz, J. Chem. Soc., Chem. Commun. 1991, 264-266.

*** 40. "Effects of Phosphine on Structure and Reductive Elimination Reactions of $\left(\mathrm{C}_{5} \mathrm{Me}_{5}\right) \mathrm{Rh}\left(\mathrm{PR}_{3}\right) \mathrm{PhH}$ Complexes", William D. Jones and Valeric L. Kuykendall, Inorg. Chem. 1991, 30, 2615-2622.

*** 41. "Multiple $\eta^{2}$ Arene Coordination. Structure and Isomerism of Naphthalene Complexes of $\left[\left(\mathrm{C}_{5} \mathrm{Me}_{5}\right) \mathrm{Rh}\left(\mathrm{PMe}_{3}\right)\right]$," Robert M. Chin, Lingzhen Dong, Simon B. Duckett, and William D. Jones, Organometallics 1991, 10,871-876. 
*** 42. "A Model for Homogeous Hydrodesulfurtzation. The Importance of $\eta^{2}$ and Sulfur Coordination in C-H and C-S Bond Cleavage Reactions of Thiophene," Lingzhen Dong, Simon B. Duckett, Kristine F. Ohman, and William D. Jones, J, Am. Chem. Soc, 1992, 714, 151-160.

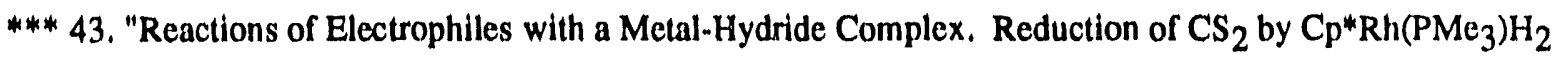
to Produce the Bridging Methanedithiolate Complex $\mathrm{Cp} * \mathrm{Rh}\left(\mathrm{PMe}_{3}\right)\left(\mathrm{SCH}_{2} \mathrm{~S}\right)$ ", William D. Jones and Anthony D. Selmeczy, Organometallics, 1992,11, 889-893.

*** 44. "Synthesis and Structure of Rhodium Complexes Containing a Photolabile $\eta^{2}$-Carbodiimide Ligand. 1,3-Dipolar Cycloaddition of Phenylazide to $\mathrm{Tp}$ 'Rh(CNR) 2 (Tp'=hydrotris(3,5dimethylpyrazolyl)borate)", Edward T. Hessell and William D. Jones, Organometallics 1992, 11, 1496-1505.

* Acknowledge DOE support between Junc 1, 1983 and May 30, 1986.

** Acknowledge DOE support between June 1, 1986 and November 30, 1989.

*** Acknowledge DOE support between November 30, 1989 and the present. 


\section{Papers in press or submitted}

1. Energetics of Organometallic Species, "The Role Of Bond Energies In Hydrocarbon Activation By Transition Metal Centers", William D. Jones, R. Martin Chin, Lingzhen Dong, Simon B. Duckett, and Edward T. Hessell, Kluwer academic publishers, in press, 1992.

2. "Catalytic Thermal C-H Activation with Manganese Complexes: Evidence Fui $\eta^{2}-\mathrm{H}_{2}$ Coordination in a Neutral Manganese Complex and its Role In C-H Activation", Mingxin Fan and William D. Jones, Organometallics, in press.

3. "Mechanism of Reductive Elimination of Benzene from $\mathrm{Tp} / \mathrm{Rh}(\mathrm{H})(\mathrm{Ph})(\mathrm{CN}$-neopentyl) in the Presence of Neopentylisocyanide", William D. Jones and Edward T. Hessell, J. Am. Chem. Soc., in press.

4. "Matrix Isolation and Transient Photochemistry of $\mathrm{Ru}(\mathrm{dmpe})_{2} \mathrm{H}_{2}$. Characterization and Reactivity of Ru(dmpe) ${ }_{2}$ (dmpe = bis(dimethylphosphino)ethane)," Chris Hall, William D. Jones, Roger J, Mawby, Robert Osman, Robin N. Ferutz, and Michael K. Whittlesey, J. Am. Chem. Soc., submitted.

5. "An Unorthodox.Reaction of Indene with $\mathrm{ReH}_{7}\left(\mathrm{PPh}_{3}\right)_{2}$ : The Competitive Formation of an $\eta^{5}$-Indanyl Ligand vs and $\eta^{5}$-Indenyl Ligand," Glen P. Rosini and William D. Jones, J. Am. Chem. Soc., submitted.

6. "Photolysis of $\mathrm{Tp} \mathrm{Rh}\left(\mathrm{CN}\right.$-neopentyl) $\left(\eta^{2}-\mathrm{PhN}=\mathrm{C}=\mathrm{N}\right.$-neopentyl) in Alkanes and Arenes: Kinetic Selectivity of [Tp'Rh(CN-neopentyl)] for Various Types of C-H Bonds," William D. Jones and Edward T. Hesscll, J. Am. Chem. Soc., submitted.

7. " $\eta 2$-Coordination and C-F Activation of Hexafluorobenzene by Cyclopentadienyl Rhodium and Iridium Complexes," Simon T. Belt, William D. Jones, Madeleine Helliwell, Martin G. Partridge, and Robin N. Perutz, J. Am. Chem. Soc., submitted.

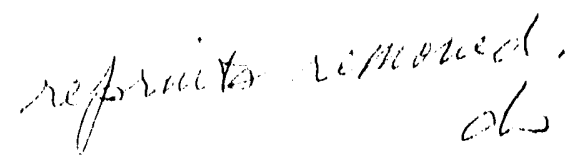



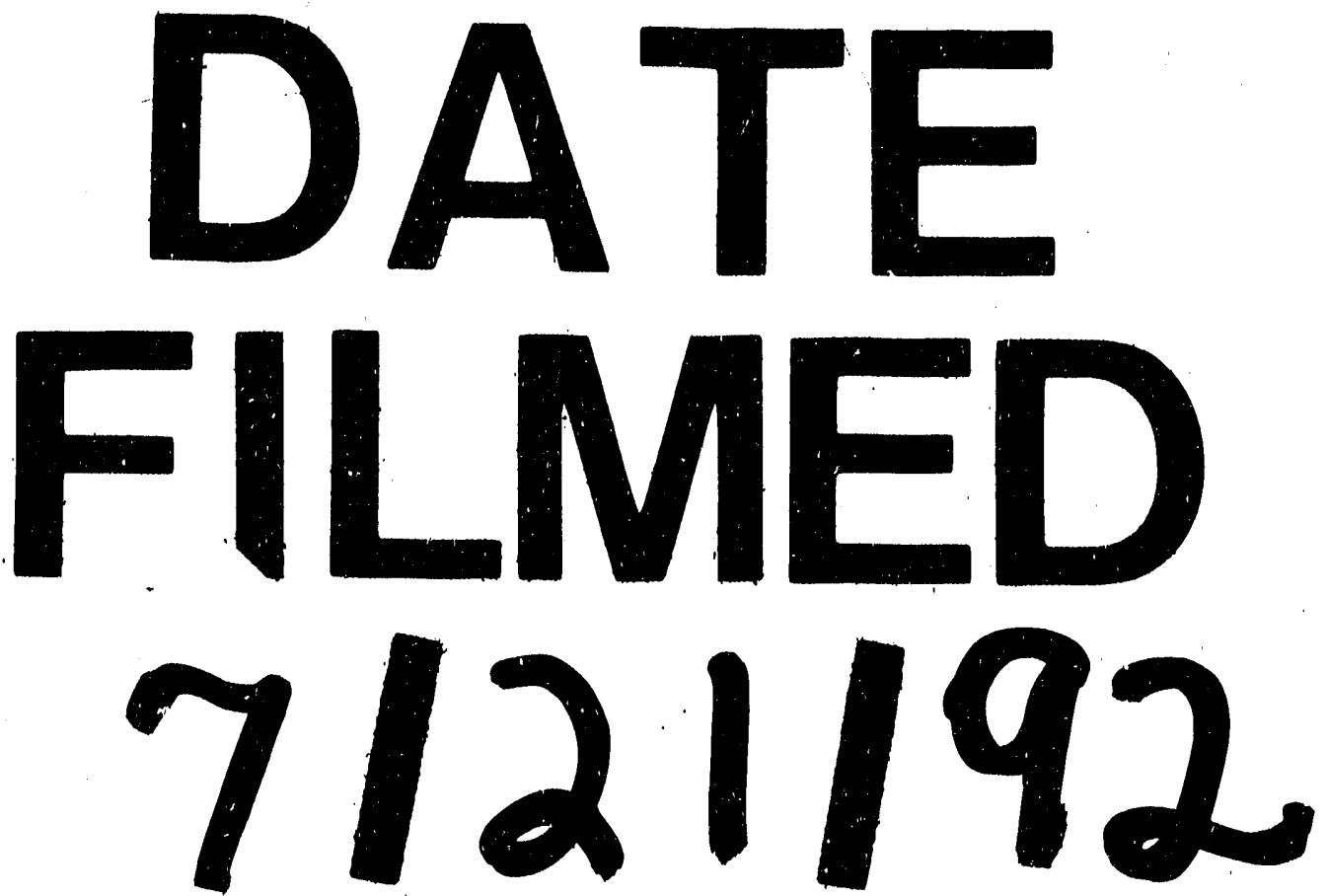
